\title{
Research Paper \\ The Effects of Mindfulness-based Stress Reduction (MBSR) on Fear of Negative Evaluation, Changing Attitude Towards Life and Assertiveness in Neglected Adolescents
}

\author{
Ziba Barghi Irani*1 \\ 1. Assistant Professor, Department of Psychology, Payame Noor University, Tehran, Iran
}

Citation: Barghi Irani Z, The effects of mindfulness-based stress reduction (mbsr) on fear of negative evaluation, changing attitude towards life and assertiveness in neglected adolescents. Quarterly Journal of Child Mental Health. 2020; 7(1): 15-31.

http://dx.doi.org/10.29252/jcmh.7.1.3

\section{A R T I C L E I N F O}

\section{Keywords:}

Mindfulness-based stress reduction (MBSR), fear of negative evaluation, change of attitude towards life, assertiveness, neglected adolescents

Received: 14 Feb 2018 Accepted: 25 Jun 2018 Available: 5 May 2020

\begin{abstract}
A B S T R A C T
Background and Purpose: The family is the core of society, which is very effective in promoting the development of children in various aspects. The child who enjoys full love of the parents will be more adaptable, comfortable, elf-confidient, and ethical. This study was done to investigate the effectiveness of mindfulness-based stress reduction (MBSR) on fear of negative evaluation, change of attitude toward life, and assertiveness in neglected male adolescents.

Method: It was a pretest-postest experimental study with control and 1-month-follow-up group.The sample included 30 neglected teenagers studying at Imam Khomeini School of Bazargan city during the academic year 2016-2017, who were randomly assigned to the experimental and control groups . The experimental group received ten 90-minute sessions of MBSR. The research instruments were Fear of Negative Evaluation Scale (Leary, 1983), Quastionare on Attitude Change (Bautista, 1973), and Assertiveness Inventory (Gambrill \& Richie, 1975). Data were analyzed by repeated measures ANOVA.

Results: Findings showed that MBSR was effective in reducing the fear of negative evaluation, changing the attitude towards life, and experiencing assertiveness in the participants of the experimental group $(\mathrm{P} \leq .001)$.

Conclusion: Based on the results of the present study, it can be concluded that through increasing awareness of the present experiences and enhancing the attention to the cognitive system and by more efficient processing of the information, the intervention used in this study led to the reduction of worry and anxiety and change of attitude towards life. Besides, whereas mindfulness causes emotion regulation without prejustice, increases the individual's awareness of his physical and mental feelings and helps in dealing with different emotions and problems, therefore, it can play a role in regulating the mental health and decreasing the fear of negative evaluation.
\end{abstract}

\footnotetext{
* Corresponding author: Ziba Barghi Irani, Assistant Professor, Department of Psychology, Payame Noor University, Tehran, Iran.

E-mail addresses: Kimia2010@gmail.com
} 


\title{
اثر بخشى درمان كاهش تنيدكى مبتنى بر ذهن آكاهى بر ترس از ارزيابى منفى، تغيير نكرش به زندكى، و و

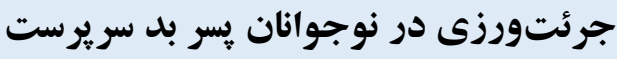

\author{
زيبا برقى ايرانى"1 \\ ا. استاديار كروه روانشناسى، دانشكده علوم تربيتى و روانشناسى، دانشگاه بيام نور تهران، ايران
}

\begin{tabular}{|c|c|}
\hline جكيده & 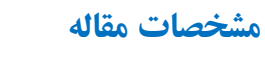 \\
\hline زمينه و هدف: خانواده هستُٔ اصلى اجتماع است كه در جهت ارتقاى تحول كود كان از جنبه هاى مختلف، بسيار مؤثر است. كودكى كه & كليدوازهها: \\
\hline در محيط خانواده از محبت سرشار بدر و مادر برخوردار باشد قدرت سازشيافتكى بيشترى داشته، احساس سكون و آرامش كرده، اعتمادبه & مديريت تنيدگى مبتنى \\
\hline خود قوى داشته، و نسبت به قوانين اخلاقى، حساس است. اين يُوهش با هدف بررسى اثربخشى درمان كاهش تنيد گى مبتنى بر ذهن آكاهى & بر ذهن آكاهى، \\
\hline بر ترس از ارزيابى منفى، تغيير نغرش به زندگى، و جرئتورزى در نوجوانان يسر بد سريرست انجام گرفته است. & 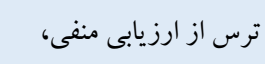 \\
\hline 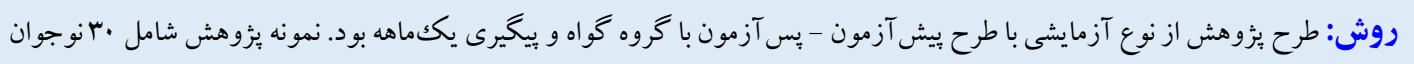 & تغيير نخرش، \\
\hline 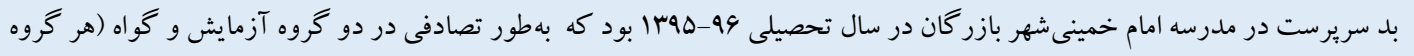 & 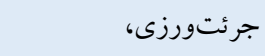 \\
\hline ها نفر) جايدهى شدند. افراد گروه آزمايش، در ده جلسه •q دقيقهاى به شيوه گروهى تحت آموزش مديريت تنيدگى قرار گرفتند. ابزار & 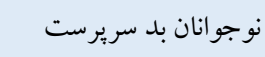 \\
\hline 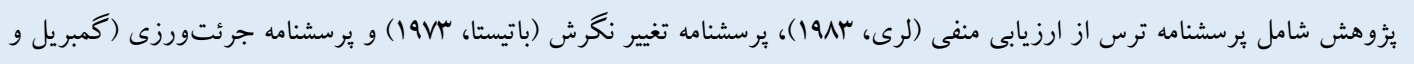 & \\
\hline ريجى، هVVD) بود. دادههاى جمع آورى شده به روش تحليل واريانس با اندازه گيرى مكرر مورد تجزيه و تحليل قرار گرفتند. & \\
\hline يافتها: نتايج نشان داد كه درمان كاهش تنيدگى مبتى بر ذهن آكاهى در كاهش ترس از ارزيابى منفى و تغيير نخرش به زندگى و & \\
\hline 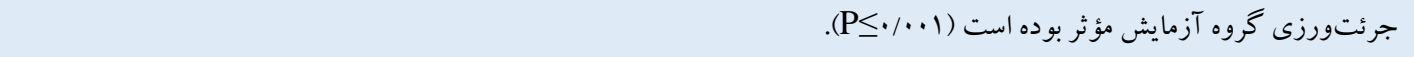 & \\
\hline نتيجه كيرى: بر اساس يافتهاى يزوهش حاضر مى توان نتيجه كرفت كه روش مداخله به كار كرفته شده در اين مطالعه با افزايش آكاهى & \\
\hline فرد از تجربيات لحظه حال و افزايش توجه به سيستم شناختى و يردازش كار آمدتر اطلاعات، باعث كاهش نخر انى و اضطراب و تغيير نخرش & \\
\hline به زندكى شده است. از سوى ديخر هون ذهن آكاهى باعث تعديل احساسات بدون قضاوت كردن و افزايش آكاهى نسبت به احساسات & 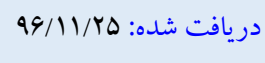 \\
\hline روانى و جسمانى مى شود و به يذيرش هيجانات و مسائل مختلف كمكك مى كند، بنابراين مى تواند در تعديل سلامت روان افراد نقش داشته & 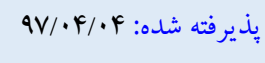 \\
\hline باشد و در نتيجه در تعديل ترس از ارزيابى منفى و افكار منفى افراد، كمكك كند. & 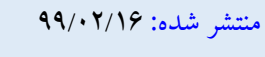 \\
\hline
\end{tabular}

* نويسنده مسئول: زييا برقى ايرانى، استاديار گروه روانشناسى، دانشكده علوم ترييتى و روانشناسى، دانشكاه هيام نور تهران، ايران.

راياناهם: Kimia2010@gmail.com

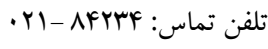


نشــان مىدهنـد كودكـانى كـه دوره ابتـدايى زنـدكىشـــان رادر

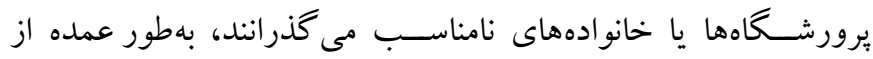

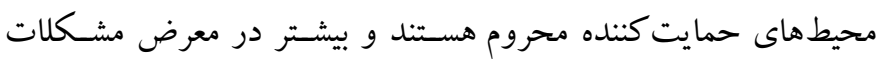
رفتارى، جسمانى، هيجانى، و اجتماعى قرار دارند (4).

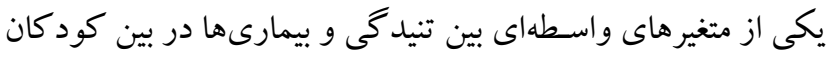

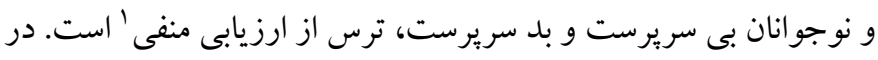

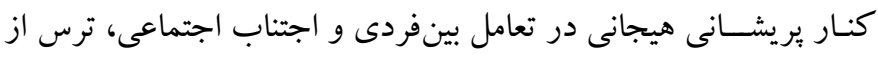

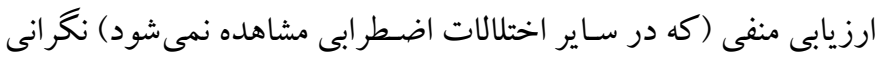

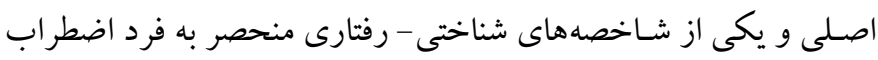

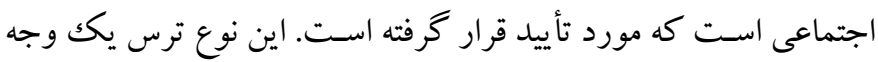

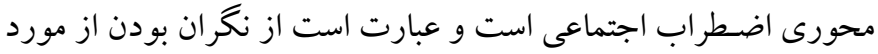

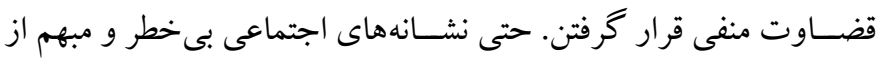

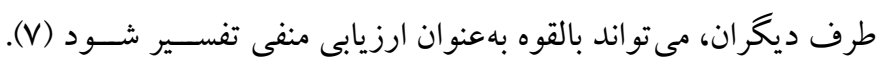
دلو إيسى، تسليم، مطيع بودن و اجتناب اجتماعى با ترس از ارزيابى منفى بـى مرتبط هســتــد. افرادى كـه نمره بالايى در مقياس ترس از ارزيابى منفى

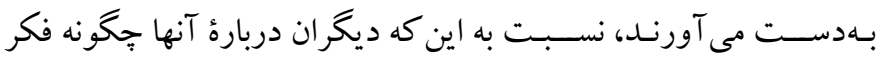

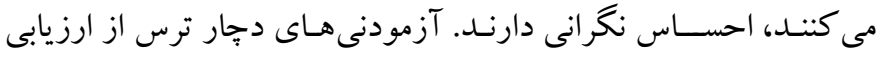

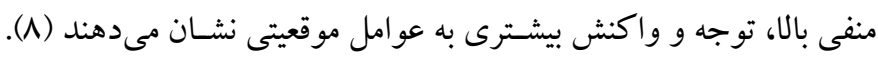

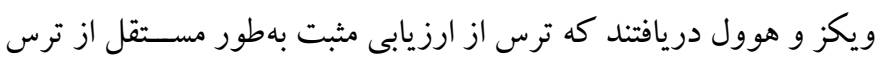
از ارزيابى منفى، سـهم معنادارى از واريانس اضـطر اب اجتماعى، عاطفه منفى در موقعيتهاى خاص اجتماعى، افكار خودكار منفى در تعاملهاى

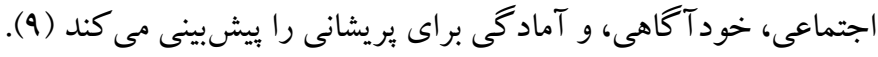

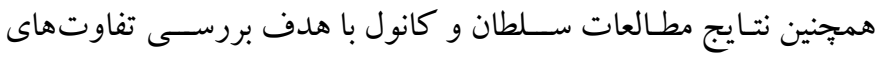
جنسيتى نشان دادند كه خود ناتوانسازى با ترس از ارزيابى منفى، رابطه مثبت معنادارى دارد. همجنين در اين مطالعه مشخص شد مردان با سطوح

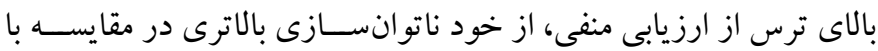

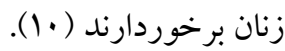
يكى ديخر از متغيرهايى كه كود كان بد سريرست با آن در خير هستند

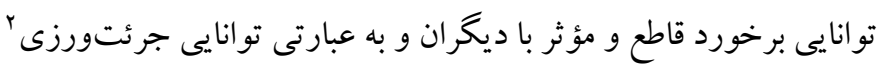

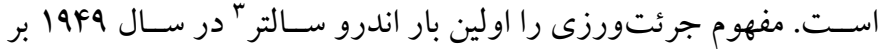

3. Androw Salter
مقلممه

خانو اده، مهم ترين عامل در ميان عو امل متعددى است كه مى تو اند باعث

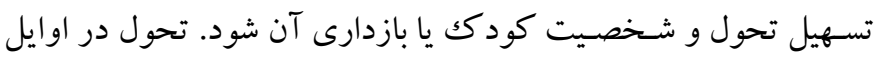
كود كى از طريق عوامل محيطى مانند خانو اده، مر اقبان، محيط اطر اف، و و

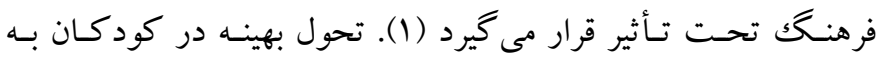

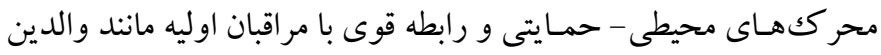

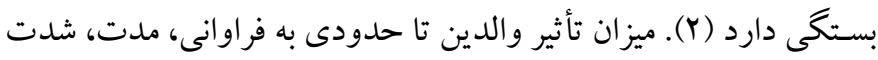
و كيفيت روابط اجتماعى آنان با فرزندانشـان مرتبط استــ آمارها نشـان

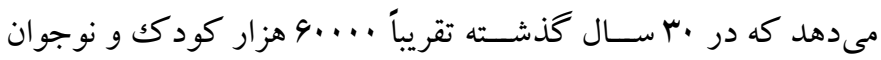
بى سـريرست و بد سـريرست به سازمان بهزيستى سيرده شدهاند. مقايسه

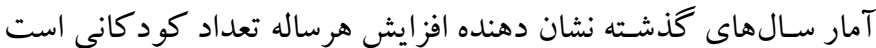

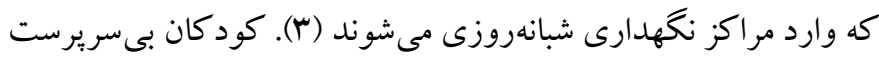

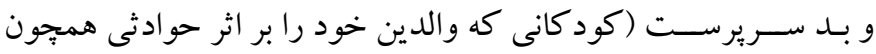

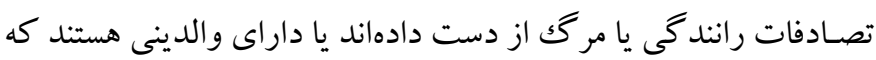
رفتار مناسـبى با فرزندان خود ندارند) از حضـور تربيتى، روانشـناختى،

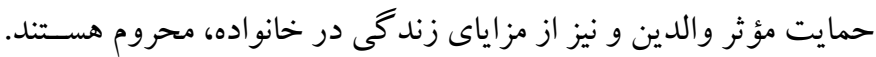

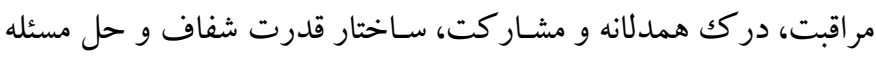

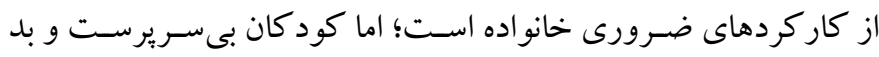
سـريرست از اين نعمت محروم هستند و در مراكز شبه خانواده (كودك در خانو اده بستگان يا خانو اده داوطلب واجد صلاحيت تحت مراقبت قرار

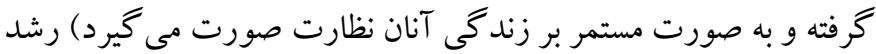

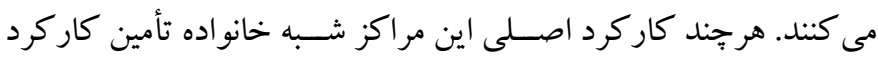

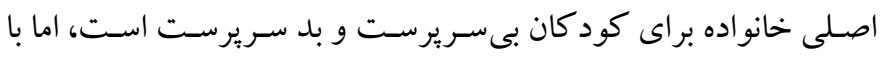

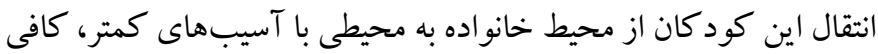

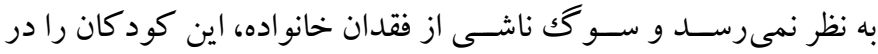

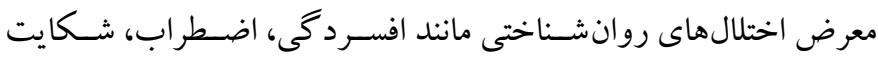

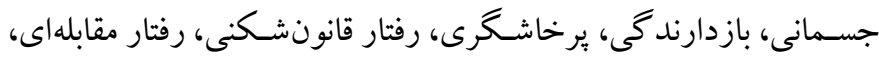

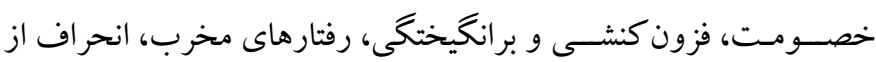

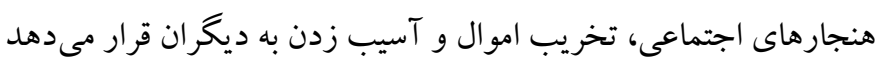

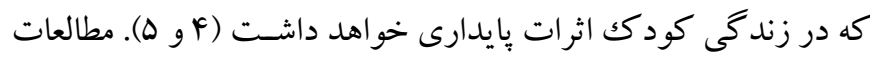

1. Fear of negative evaluation

2. Assertiveness 
كند و رابطهاش را با افكار و احسـاسـات كشاكش گرانه تغيير داده و آنها

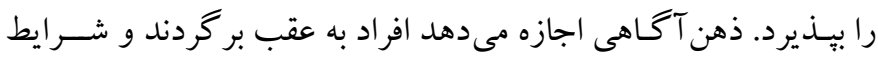

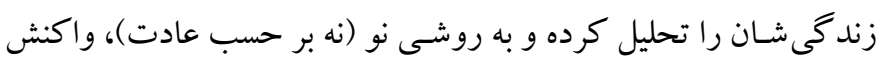

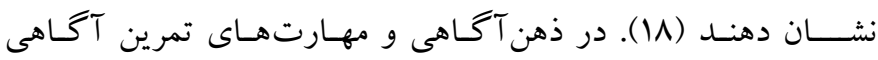

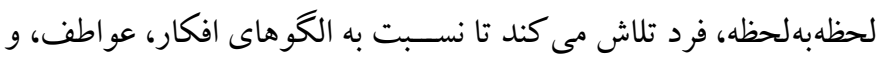

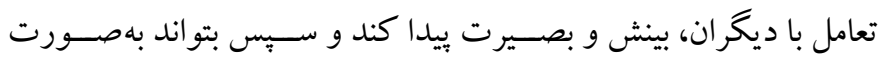

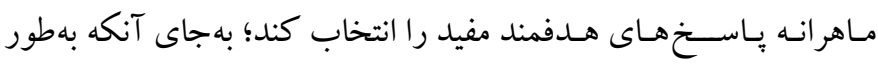

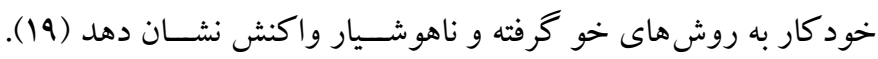
تصور مىشود كه وقتى فرد به سازههاى ذهن آكاهى دست يابد، بهزيستى و سلامت جسمانى، روانشناختى و هيجانى را بهبود بخشيده و به فرد اين

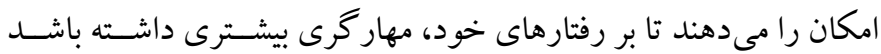

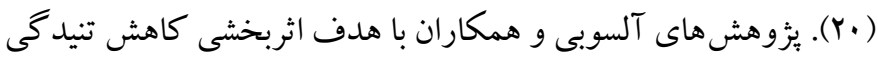
مبتنى بر ذهن آكَاهى بر اجتناب هيجانى و فراهيجان از اين نتايج حمايت

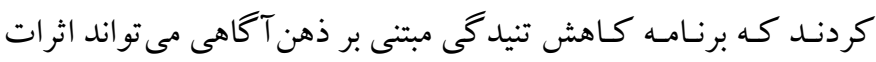

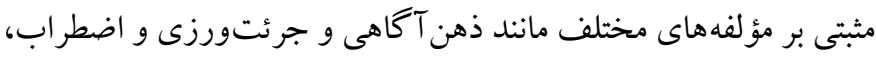
داشته باشد (N|N ا (Y). نتايج مطالعات ديويس و هيس نشان داد كه بهبود ظرفيـت حـافظه فعـال و افزايش ســــــت يردازش اطلاعات با تمرينات

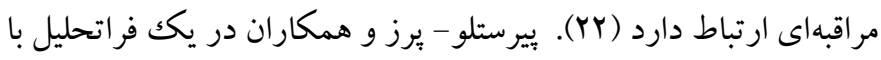

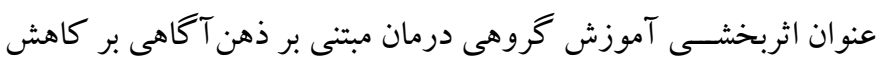

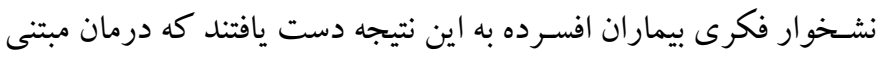
بر ذهن آكاهى بر كاهش نشـخوار فكرى بيماران افسرده تأثير مثبت دارد

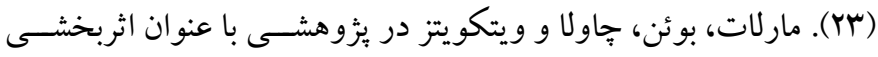

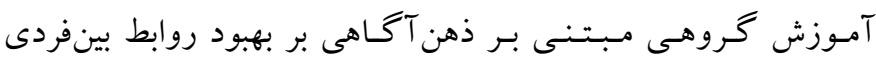

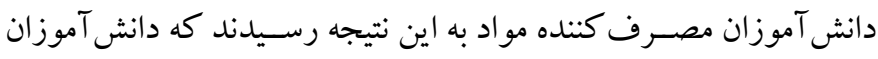

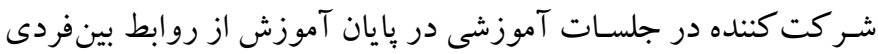

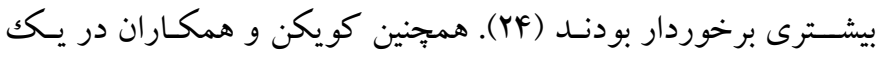

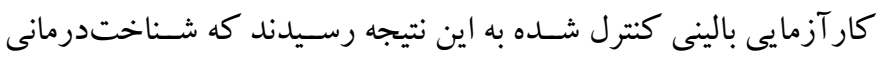

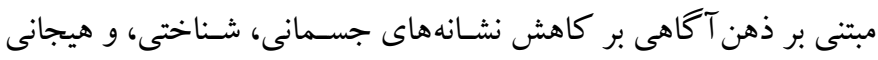

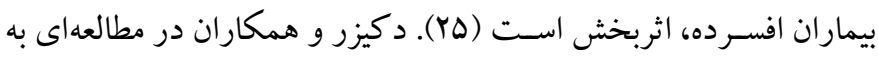

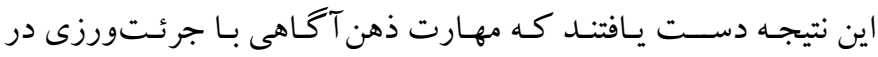

اســاس افكـار بـاولف مبنى بر تأثيريـذيرى از برانخيختخى ' و بازدارى '

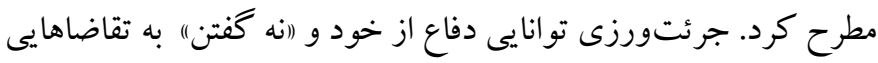

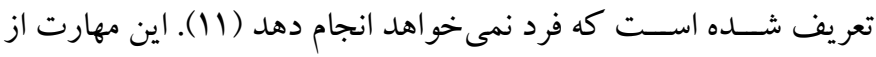
مهم ترين و اســاسـى ترين مهارتهاى اجتماعى اسـت كه در برقرارى، حفظ، و انسـجام روابط بينفردى اهميت دارد (Y) (I). جرئت ورزى شـامل احقاق حق خود، ابراز افكار و عقايد و احساسات خود به شيوه مناسب و و مسـتقيم و صـادقانه اسـت؛ به گونهاى كه حقوق ديخر ان ران را از بين نبريم. همجنين رفتارى اسـت كه شـخص را قادر مى وسـازد تا به نفع خود عمل

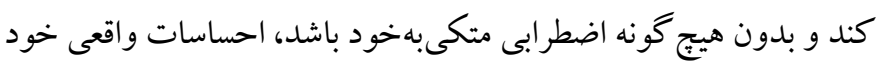

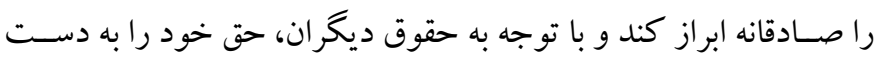

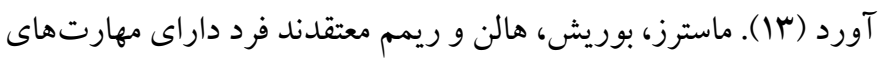

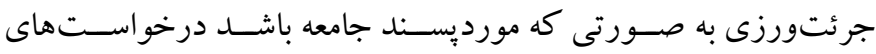

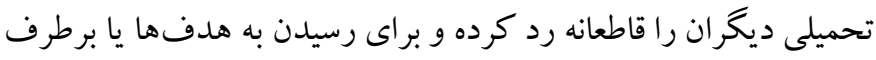
كردن نيازهاى خود، درخواستهاى خود را مطرح مى كند (If).

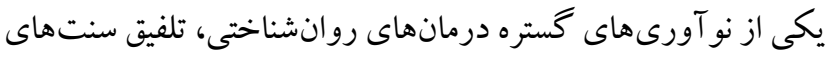
معنوى شــرق، ازجملـه فنون مراقبه تفكر نظـارهاى (ذهن آكَاهى) بـاـ

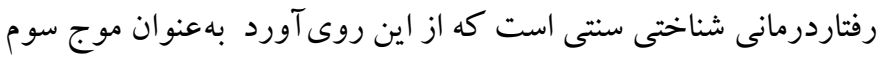

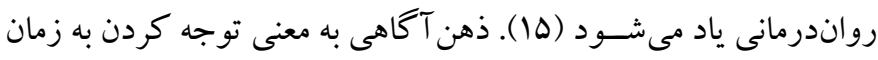

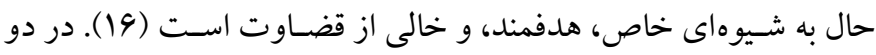

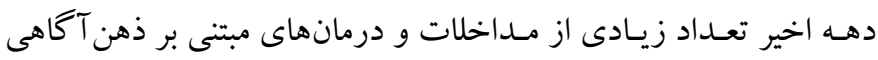

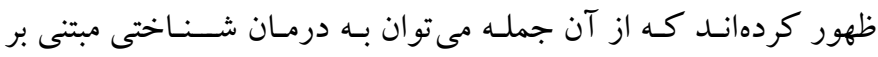

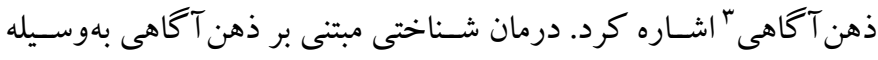

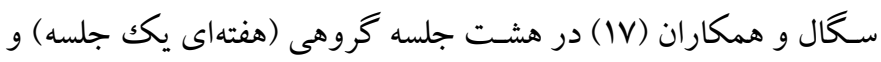

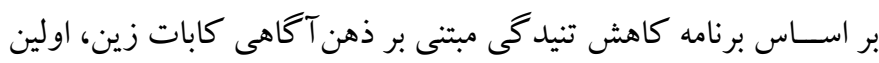

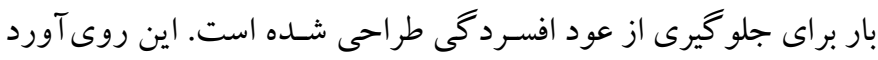

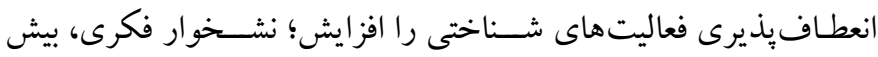

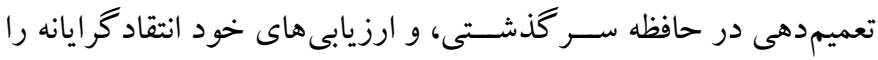

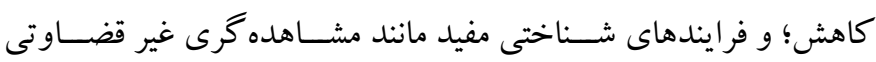
محتواى ذهنى را افزايش مىدهد. در اين شـيوه مراجع ترغيب مى شود تا تأي

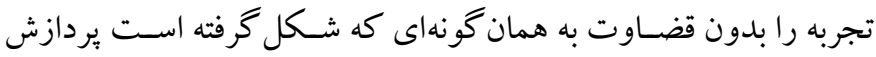

1. Arousal

2. Inhibition 
كود كان و نوجوانان است. بررسى آمارهاى موجود در حوزه حمايت و

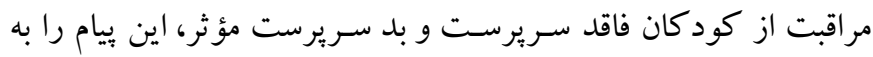

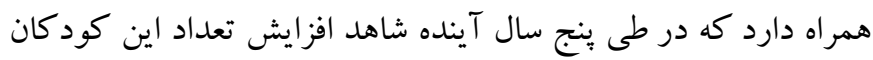

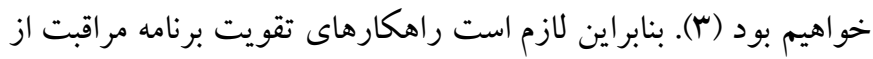

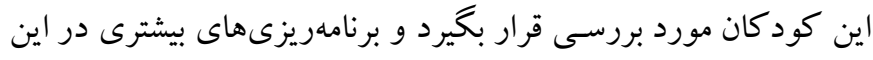

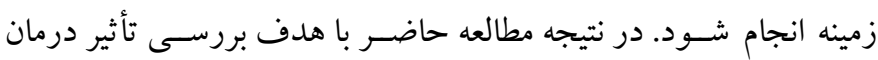

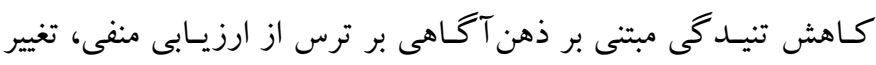

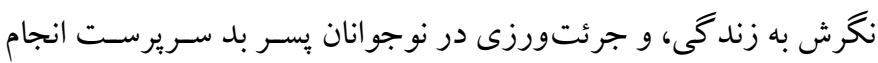
شده است.

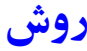

الف) طرح يزوهش و شـــ كت كنند كان: يزوه هش حاضـر آزمايشى از

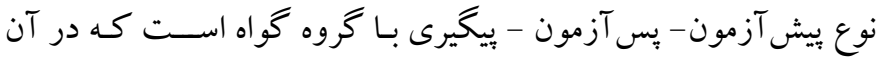

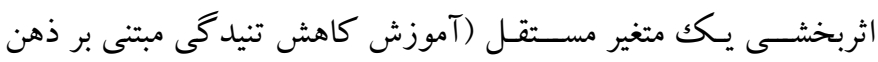

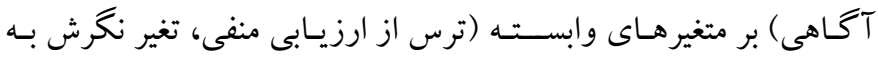

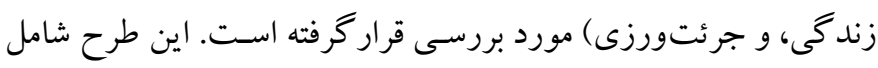

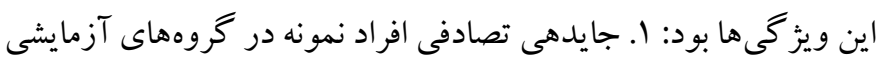

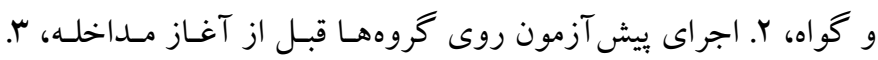

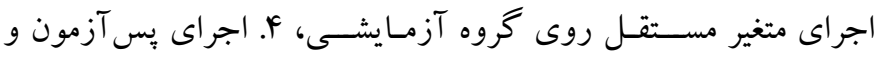

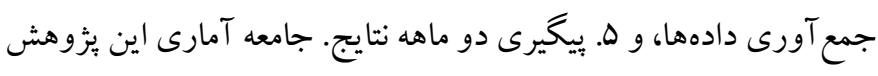

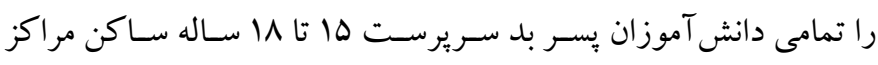

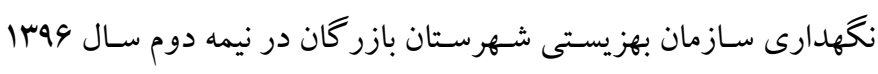

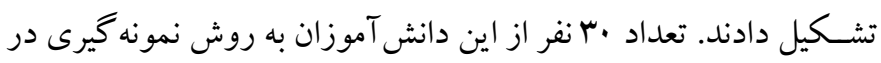

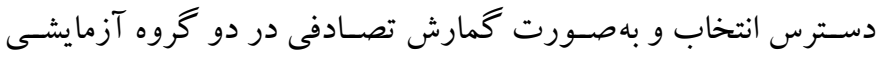

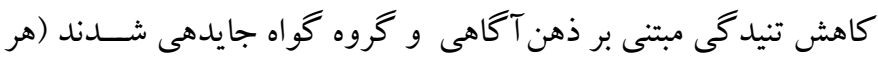

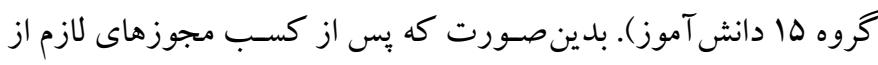

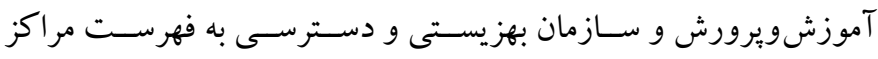

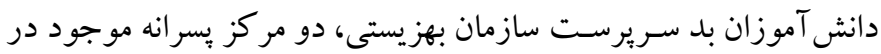

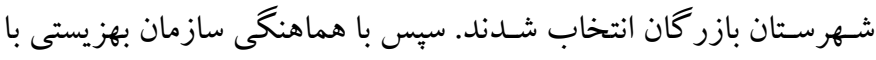

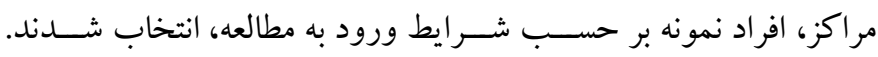

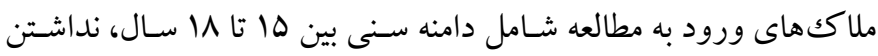
سـابقه بيمارى جسـمانى و روانشـناختى (تشـخيص اين ملاكك بهوسـيله
موقعيت هاى مختلف اجتماعى همبسـته است و تمايل بيشتر براى مشاهده آكاهانه با همدلى همبستخى دارد (Y9). از ســويى ديـر نتـايج مطـالعهـ رحمـان و همكـاران در كودكـان

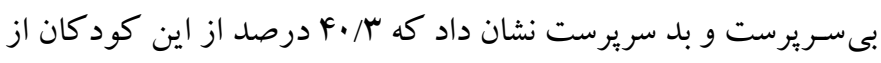

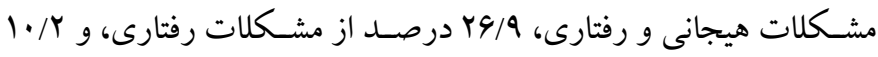
درصــد از مشـكلات عاطفى رنج مىبرند (YV). يندور كك و ســوملبا در

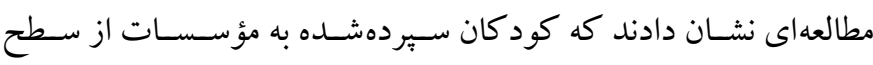

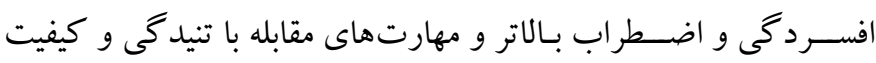
زندگى بايين ترى برخوردارند (Y^)

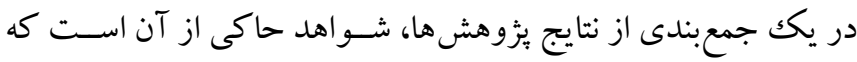
به كار گيرى روش كاهش تنيدگى مبتنى بر ذهن آكاهى بر ايجاد تغيير در

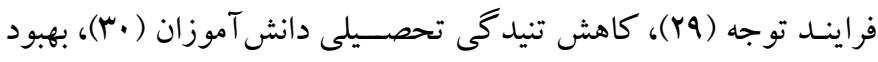

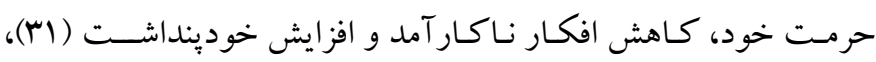

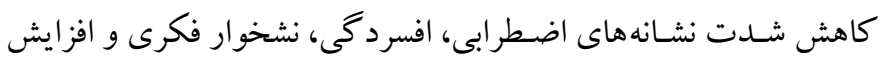

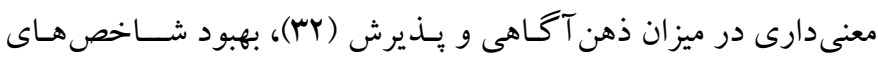

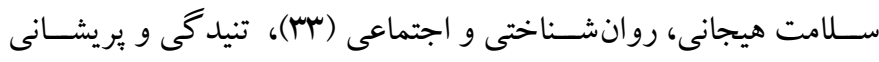

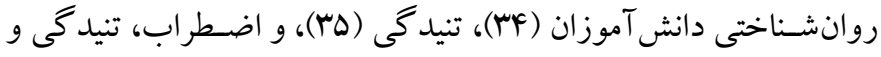

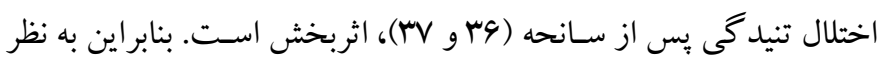

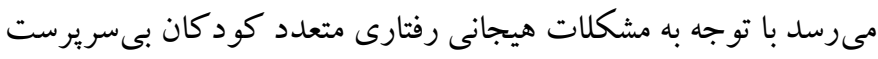

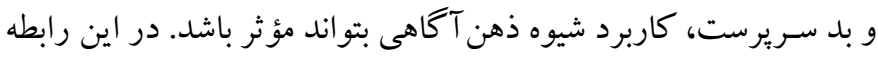

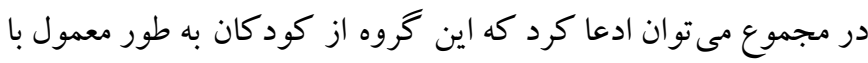
بى توجهى و غفلـت عاطفى مواجه مىشـــوند كه در نتيجه در طول

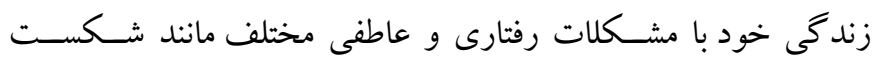

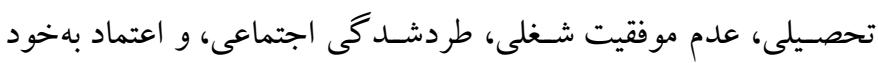
بإين، مواجهه مىشوند.

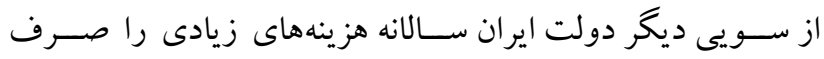

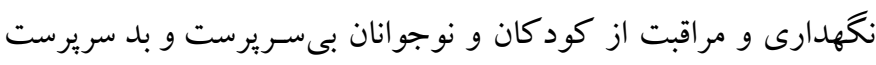

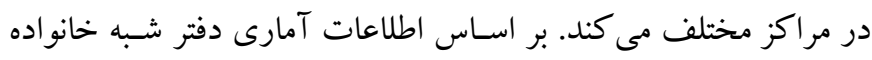

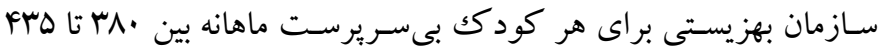
هزار تومان هزينه مىشـود. اما متأسفانه دادههاى حاصل از بررسىهاى

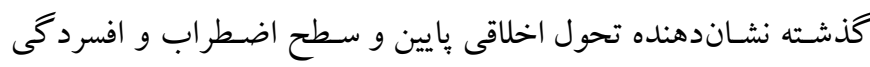

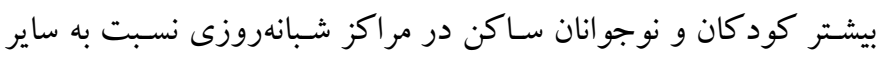


شــده اسـت. نتايج تحليل عاملى تأييدى نشـان دادند، درحالى كه الكوى

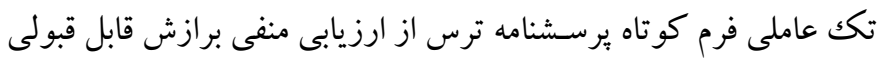

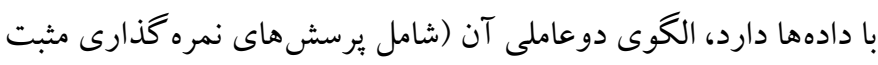

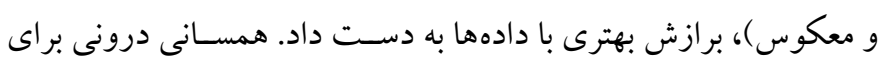

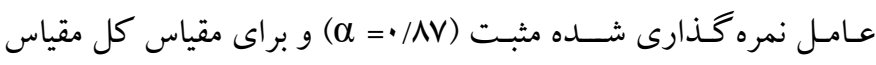

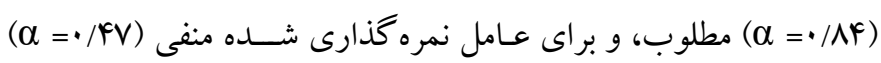
قابل قبول بود. نمرات فرم كو تاه يرسشنامه ترس از ارزيابى منفى با نمرات

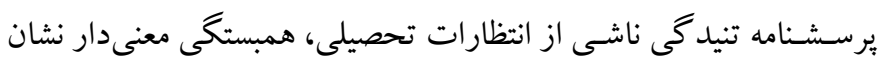

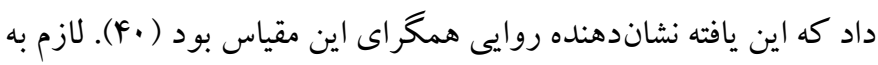

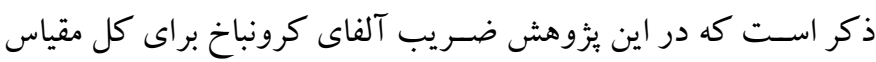

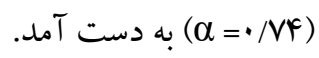

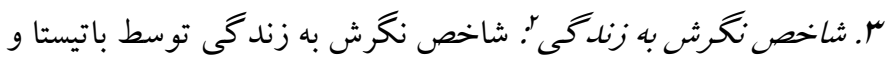

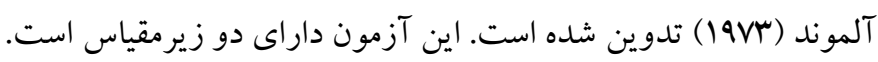

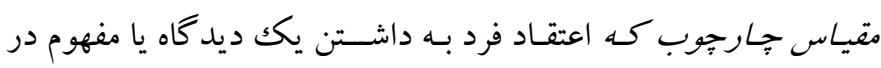

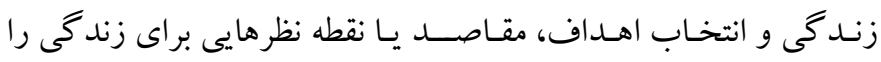

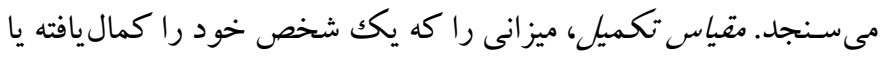

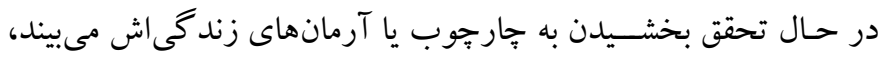

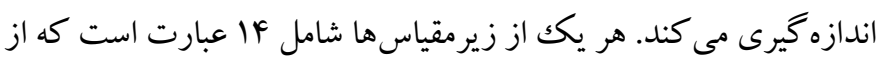
اين تعداد V Vبارت بهصسورت منفى و هفت عبارت بهصسورت مثبت بيان

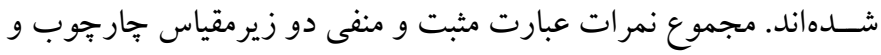

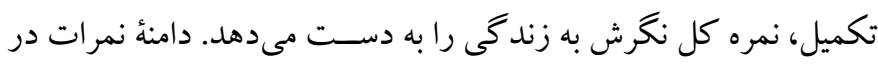

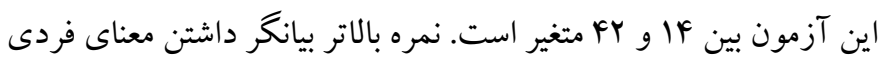

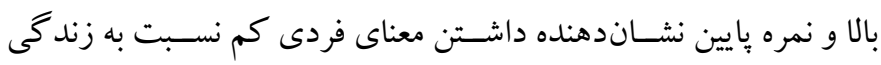

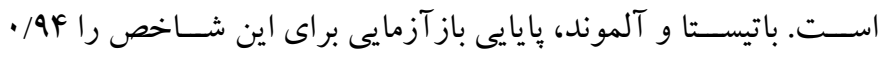

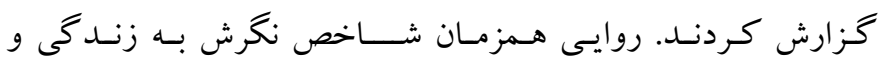

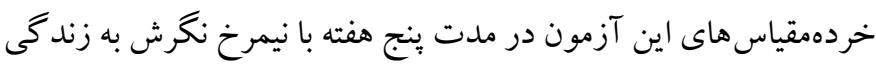
(r=·/V9)

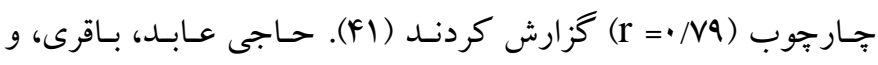

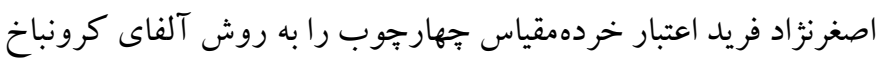

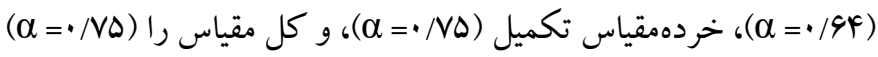

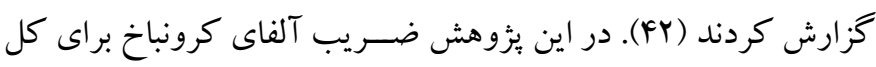

يرونده موجود در مراكز صـورت گرفت)، و r. داشستن سو اد كافى براى

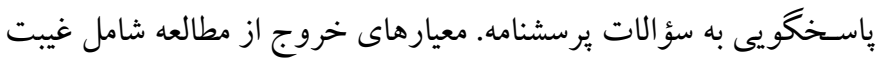

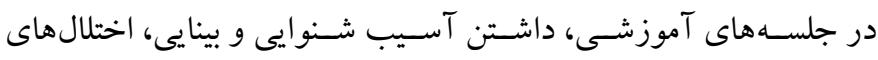

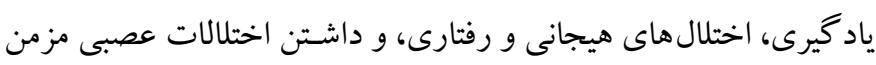

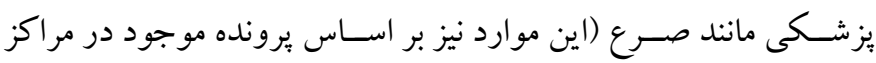
بر رسى شد).

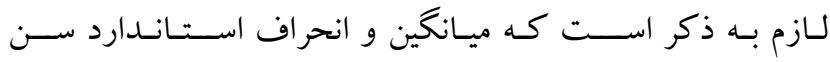

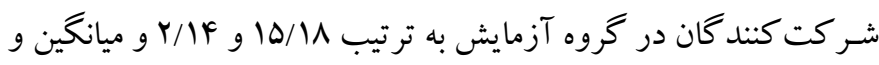

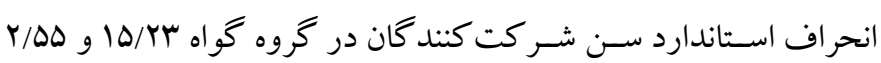
ا . سـياهه اطلاعات جمعيتشـاختى: اين مقياس توسط ئزوهشخران براى سـنجش مشـخصـات جمعيت شناختى افر اد نمونه، تنظيم شد كه به وسيله

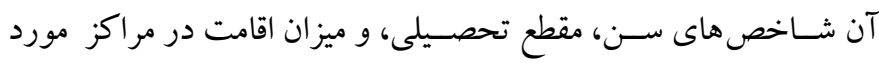
سنجش قرار گرفت.

r. مقياس ترس /ز /رزيابى منفى - فرم كوتاه ': نسخه كو تاه مقياس ترس از

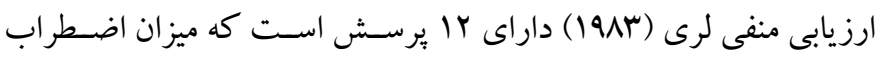

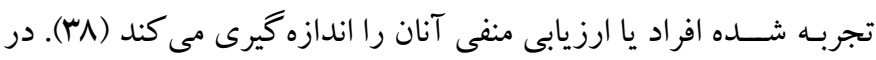

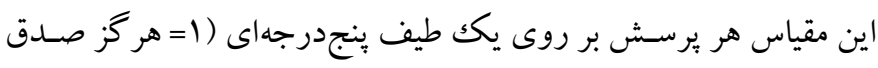

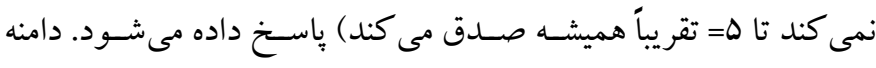

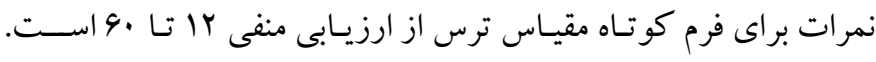

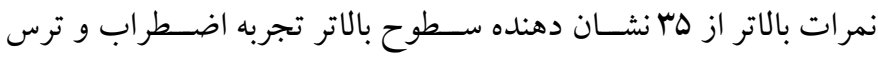

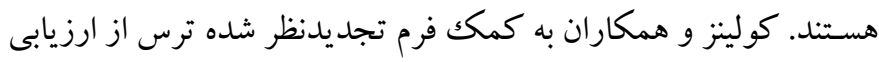

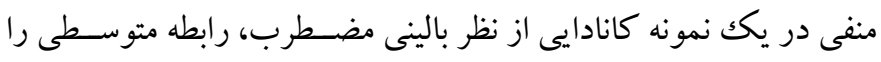

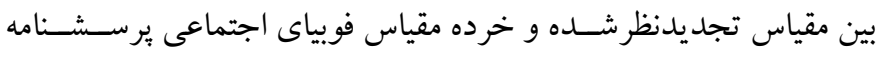

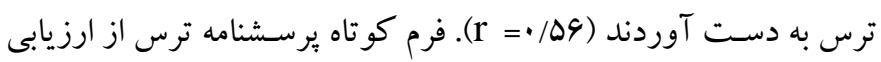

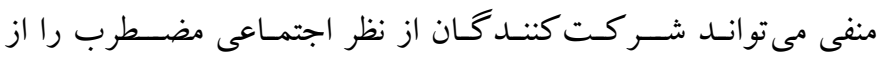
شر كت كنند گان غيرمضطرب جدا كند. اعتبار اين آزمون در نمونه بالينى

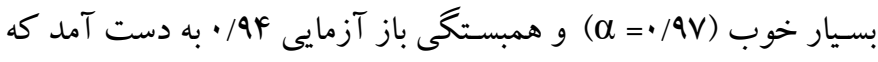

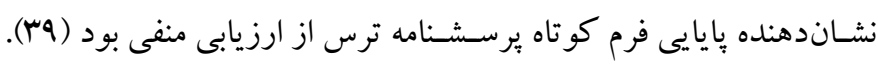
ويز گى هاى روانسـنى اين برسشنامه توسط شكرى و همكاران محاسبه 


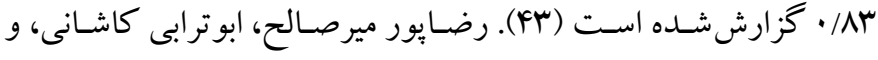

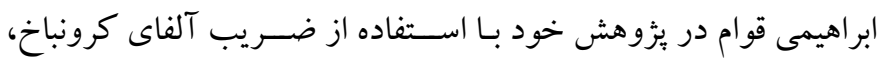

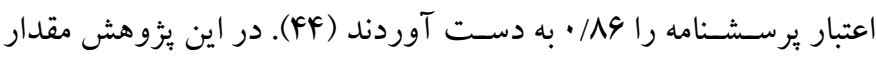
آلفاى كرونباخ براى كل مقياس (

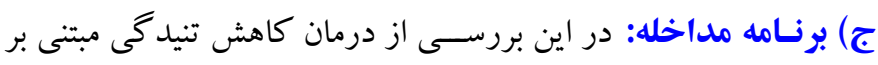

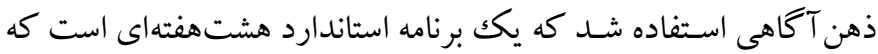

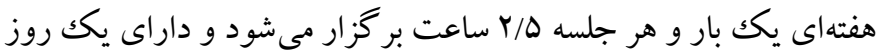

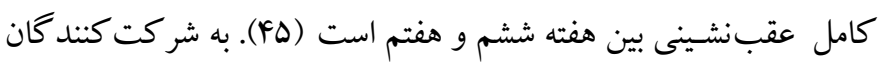

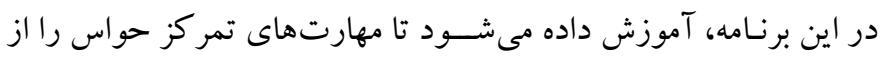
طريق طيف وسـيعى از شـيوههاى تمر كز حواس رسـمى و غيررسـمى،

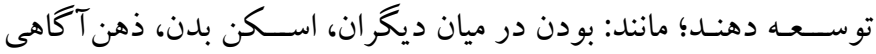

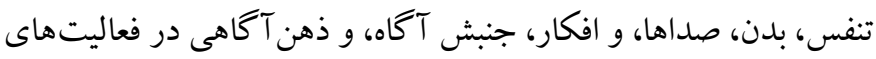

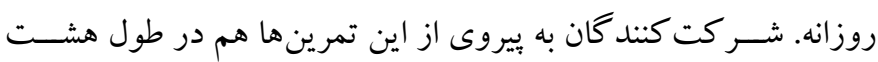

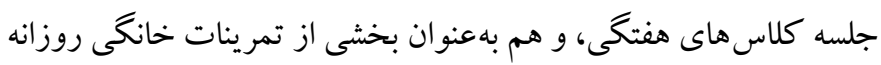

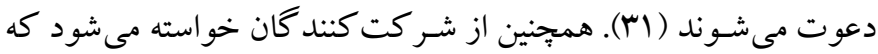

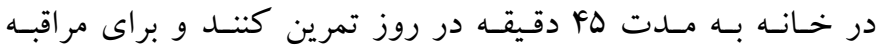

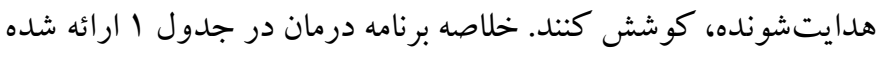

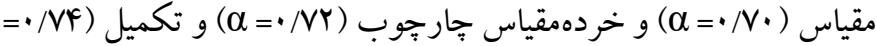

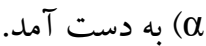

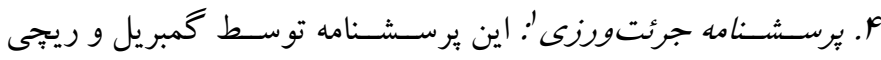

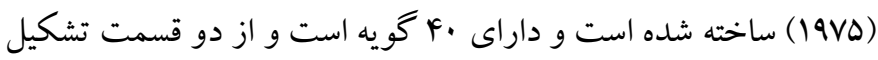
شده است كه هر گويه آن، يك موقعيت را كه مستلزم رفتار جرئتمندانه است، نشان مىدهد. در قسمت اول از آزمودنى خواسته مى شود كه ميزان

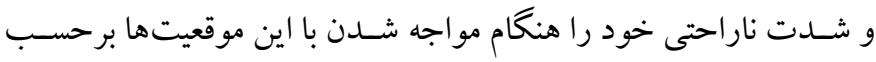

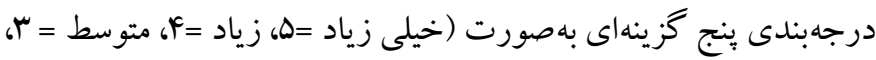

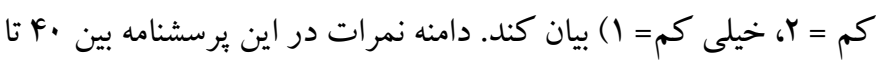
T Y... آزمون داراى جِند دسـته ســؤال اســت: الف) رد كردن تقاضـا، ب) بيان

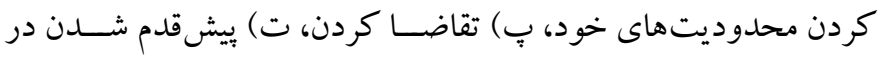
آغاز يكك برخورد احتمالى، ث) بيان احساسات مثبت، ج) كنار آمدن و و

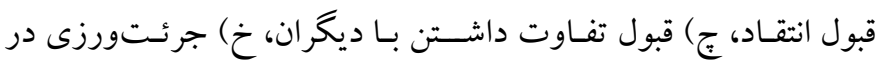
موقعيت هاى كه بايد كمك كرد، و ) دادن بِخخور اند منفى. تحليل عوامل

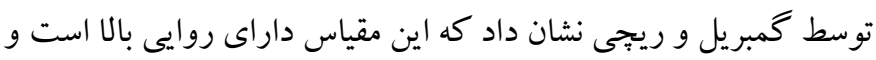

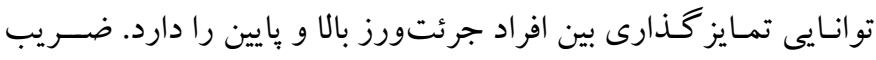

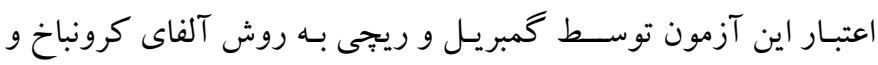

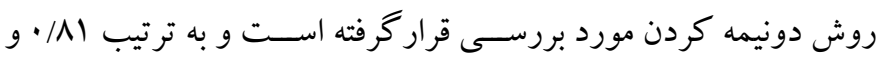

جدول ا: خلاصه جلسات درمان كاهش تنيد

\begin{tabular}{|c|c|c|c|}
\hline جزوات شر كت كنند كان & تكاليف خانكى & دستور جلسه & 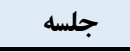 \\
\hline 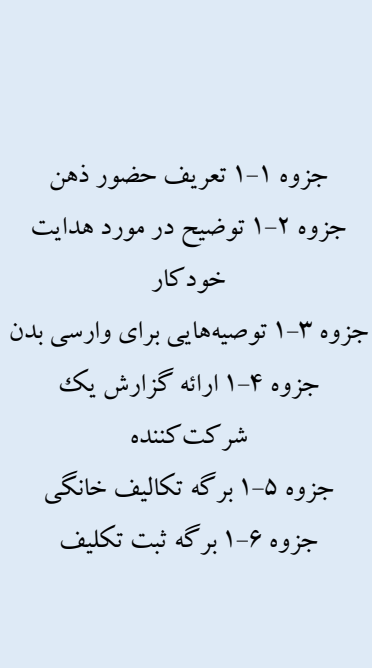 & 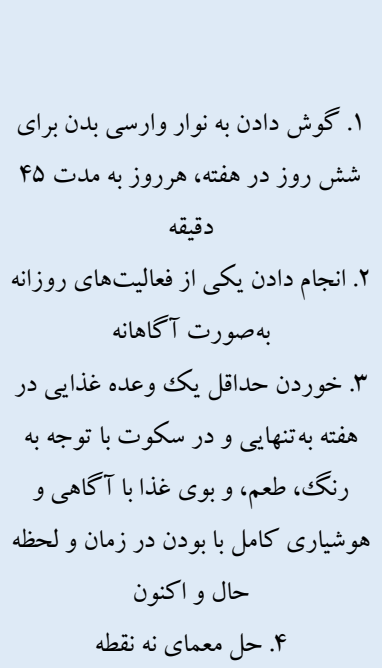 & 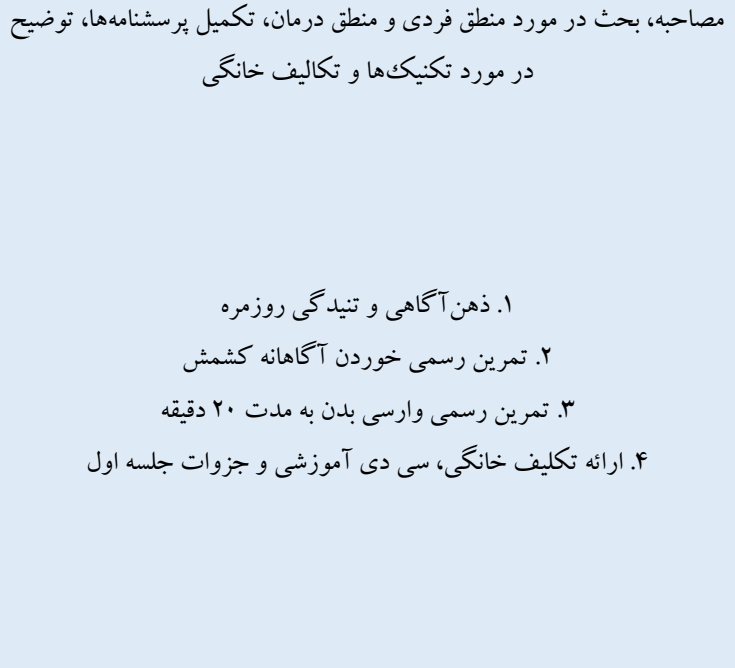 & $\begin{array}{c}1 \\
(\text { ) }(\Delta / \Delta)\end{array}$ \\
\hline
\end{tabular}

1. Assertion inventory (AI) 


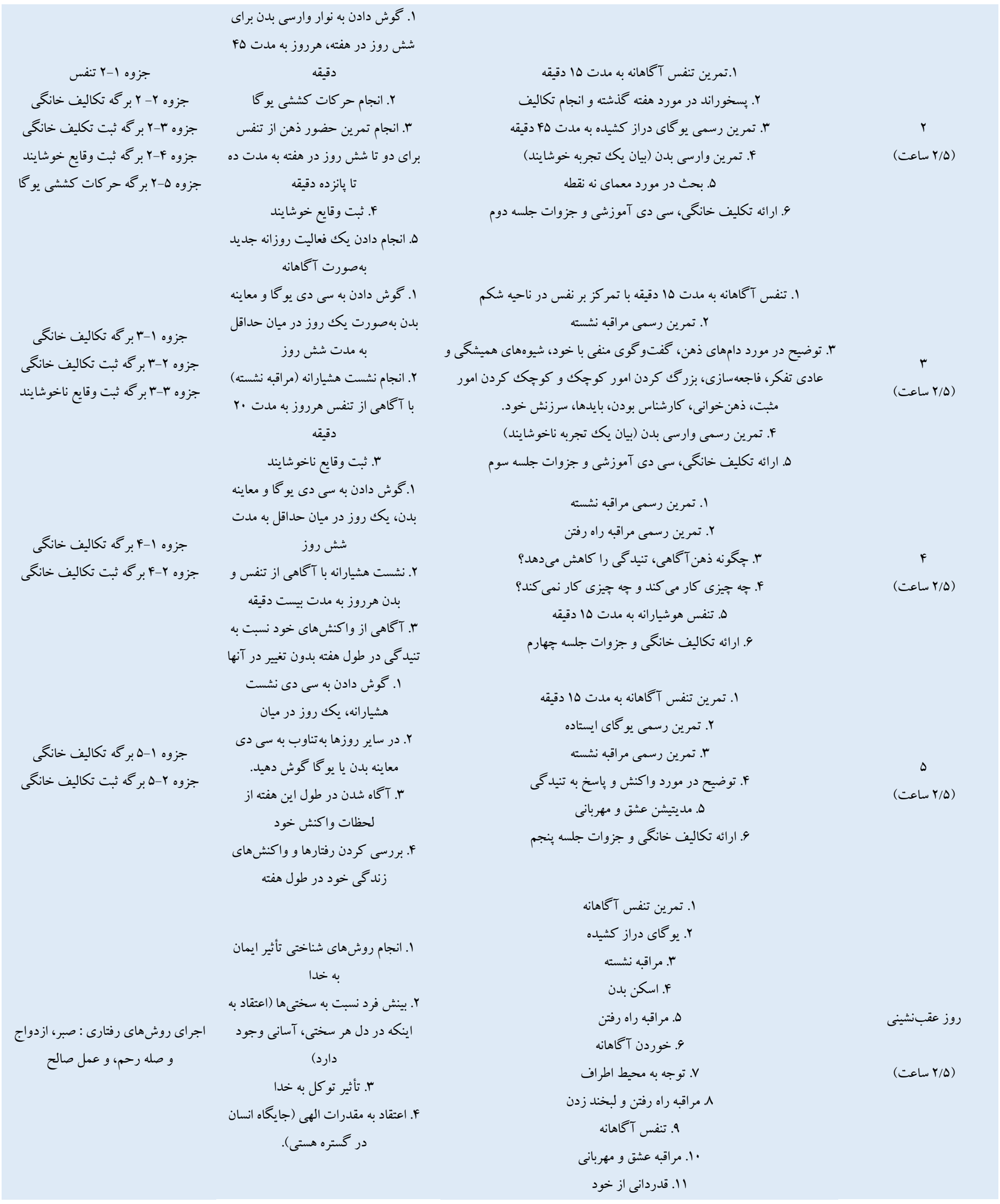




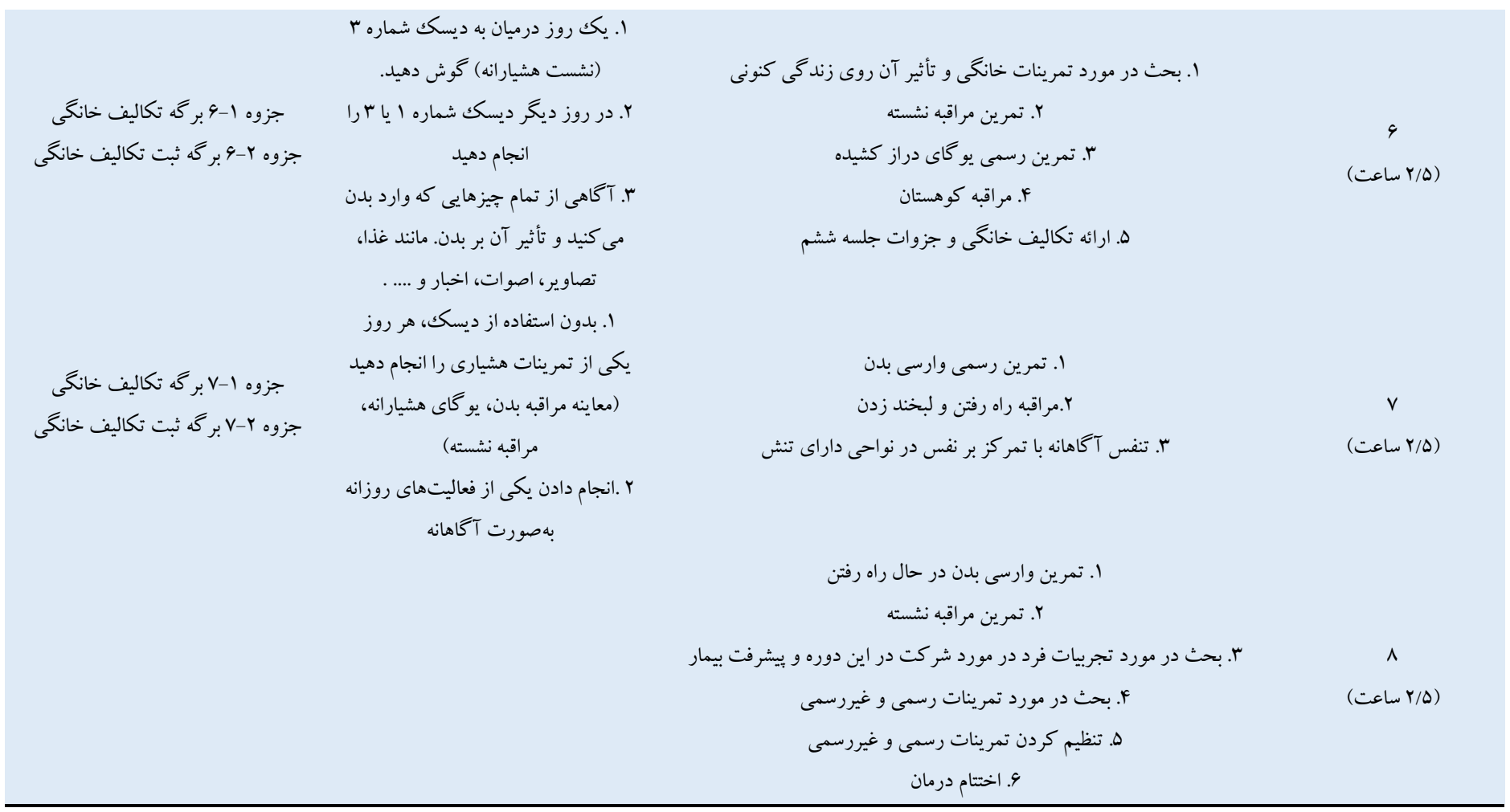

يس از جمع آورى دادهها در مرحله يِيَيرى، برنامه كاهش تنيدگى مبتنى

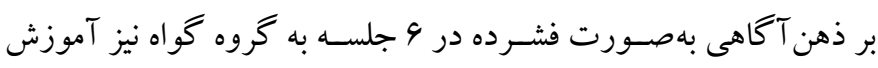

داده شد.

لازم به ذكر اسـت سـاير ملاحظات اخلاقى نيز در اين مطالعه رعايت

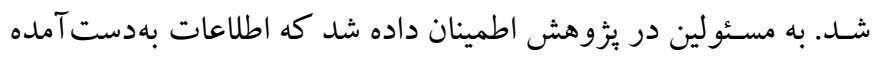

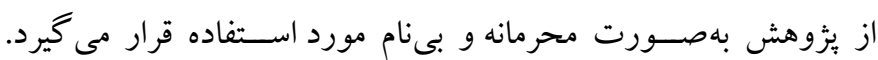

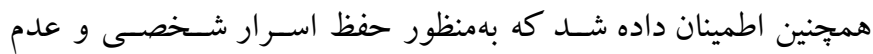
تجاوز به حريم خصوصى افراد، نتايج در سطح كلى (ميانخين) خروهـا كزارش شـده و براى مقاصـد تربيتى در اختيار روانشناسان، متخصصان

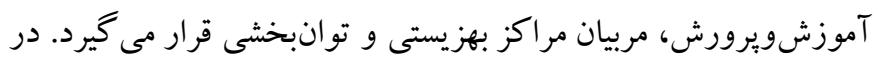
مورد عدم ضرر و زيان ناشى از شركت در بُزوهش، اطلاعات كامل در

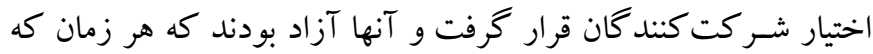
بخواهند از ادامه همكارى با يزوهشخر، خوددارى كنند.

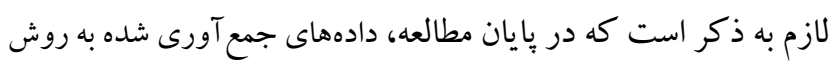
تحليل واريانس با اندازهيرى مكرر مورد تجزيه و تحليل قرار گرفتند.
د) روش اجرا: بس از كسـب مجوزهاى للازم علمى و اجرايى، ضرورت

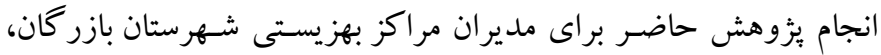

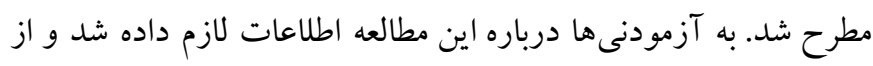

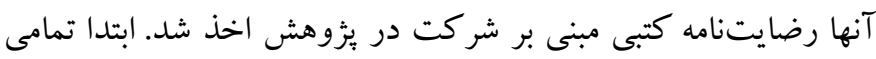

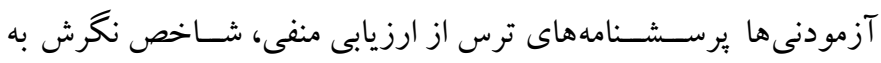

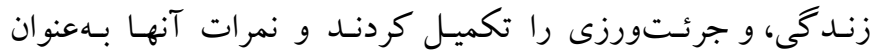

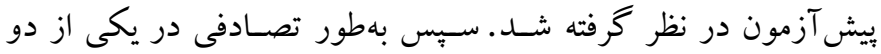

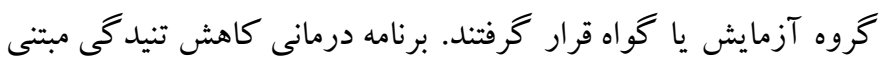

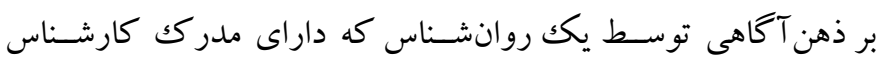
ارشــد روانشناسى بالينى بود و آموزشهاى للزم درباره درمانهاى نسل

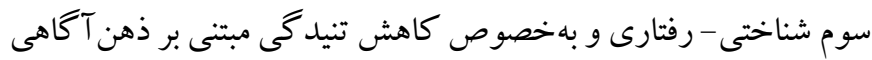

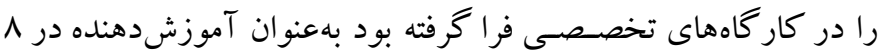

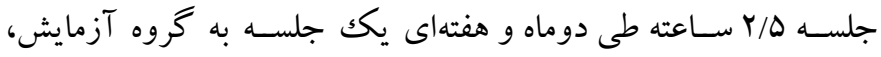

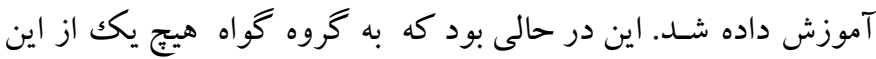

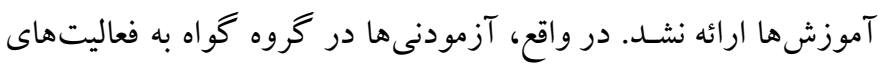
آزاد مى يرداختند؛ به نحوى تحت كنترل و مراقبت بودند. در بايان براى بردي

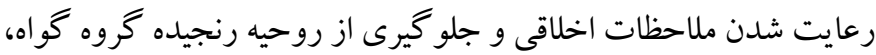


جدول rا: يافتهاى توصيفى مربوط به ترس از ارزيابى منفى، نكرش به زندكى، و

جرئتورزى

\begin{tabular}{|c|c|c|c|c|}
\hline ييغيرى & ֶֶ آزمون & يیش آزمون & كروه & متغير \\
\hline ميانگين (SD) & ميانگين (SD) & ميانكين (SD) & & \\
\hline$(\Delta / F q) r Y / q$. & $(\Delta / F \Delta) r Y / \Delta r$ & $(\Delta / Q \Delta) r Q / Y V$ & آزمايش & ترس از ارزيابى منفى \\
\hline$(F / r I) r V / \Delta r$ & $(F / R Y) Y V / Q T$ & $(F / q r) r V / q V$ & كواه & \\
\hline$(F / V) Y Q / \Delta r$ & $(\boldsymbol{F} / \cdot r) r \cdot / \mu$ & $(Y / Q 9) Y F / Y V$ & آزمايش & نغرش به زندگى \\
\hline$(r / r) Y F$ & $(Y / 99) Y F / F V$ & $(\Gamma / \Gamma T) Y F / A V$ & كواه & \\
\hline$(\mid r / r \cdot) \mid r \cdot / F q$ & $(\mid r / \Delta r) \mid r \cdot / F V$ & $(11 / 41) 9 V / 9$ & آزمايش & جرئتورزى \\
\hline$(11 / \Gamma V) 9 \Delta / 9$ & $(I Y / Y F) q V / F V$ & $(\mid r / Y 9) 9 \Delta / 9$ & كواه & \\
\hline
\end{tabular}

با توجه به جدول ب در گروه آزمايش ميانگين ترس از ارزيابى منفى

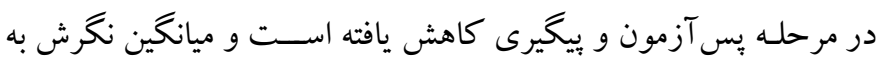

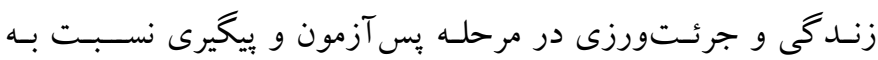

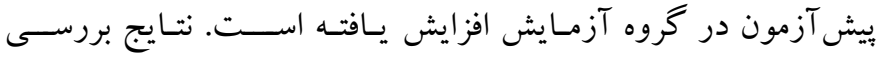

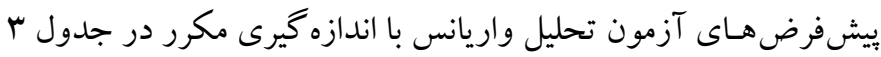
كزارش شده است.
يافتهها

براى تحليل دادههـا، ابتدا توزيع نرمال متغيرهاى بُزوهش مورد بررسـى

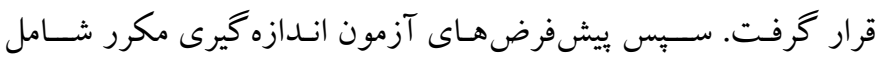

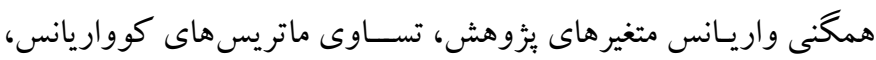

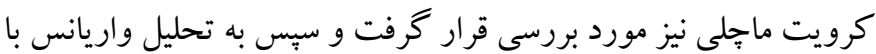

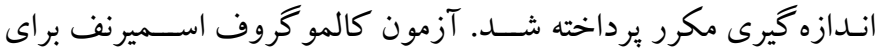

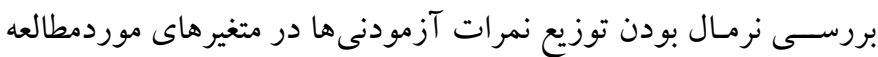

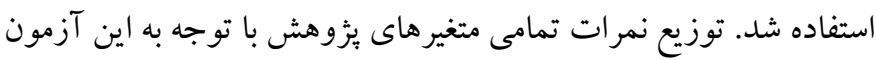

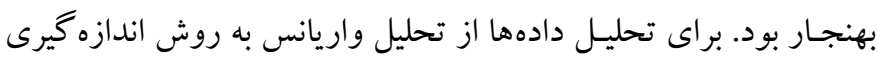

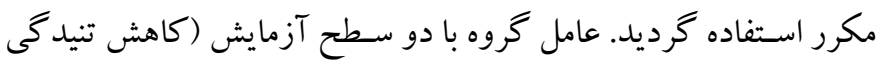

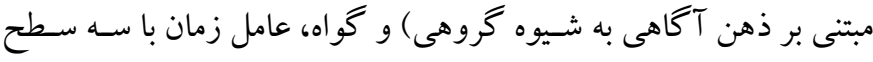

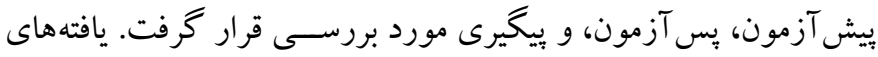

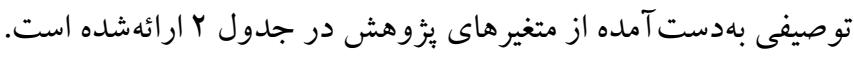

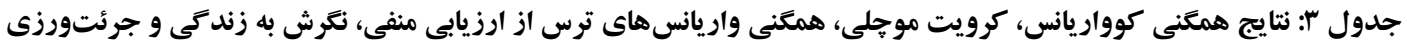

\begin{tabular}{|c|c|c|c|c|c|}
\hline \multicolumn{3}{|c|}{ لوين } & \multirow{2}{*}{ كرويت موجلى (خى دو) } & \multirow{2}{*}{ ام باكس (f) } & \multirow{2}{*}{ متغير } \\
\hline بيغيرى & يس آزمون & يِيش آزمون & & & \\
\hline .1 .99 & $\cdot / \Delta 1 V$ & $1 / 211$ & $(Y / F \Lambda) \cdot / Q F$ & $(Y / 9 F \cdot) 19 / 91$ & ترس از ارزيابى منفى \\
\hline $\mathrm{P}=\cdot / \mathrm{\vee \Delta}$ & $\mathrm{P}=\cdot / \notin \vee \Lambda$ & $\mathrm{P}=\cdot / r \cdot 1$ & $\mathrm{P}=\cdot / 4 \mid r$ & $\mathrm{P}=\cdot / \cdot \cdot 1$ & \\
\hline r/TAG & F/AGT & $\cdot / / q \Delta$ & $(\% / \cdot 1) \cdot / \wedge q \vee$ & $(r / r V r)$ rr/QYG & نغرش به زندگى \\
\hline $\mathrm{P}=\cdot / 111$ & $\mathrm{P}=\cdot / \cdot F F$ & $\mathrm{P}=\cdot / \Delta r \Delta$ & $\mathrm{P}=\cdot / 1 \cdot r$ & $\mathrm{P}=\cdot / \cdot \cdot 1$ & \\
\hline .1 .09 & $\cdot 1 \cdot \sqrt{9}$ &.$/ 019$ & $(Y \backslash / ৭ ৭ \Delta) \cdot / F F r$ & $(G / Y \Delta Q) F Y / \Delta Y V$ & جرئتورزى \\
\hline.$/ 9 T V$ & $\cdot /$ VAD &.$/ 4 \vee q$ & $\mathrm{P}=\cdot / \cdot \cdot 1$ & $\mathrm{P}=\cdot / \cdot \cdot 1$ & \\
\hline
\end{tabular}

تصـادفى بوده اسـت از اين مفروضه براى متغير جرئتورزى جشميوشى مى كنيم. نتايج آزمون لوين نشـان داد كه مفروضسه همخنى واريانس هاى خطاى ترس از ارزيابى منفى، نكرش به زندگىى، و جرئتورزى دو گروه

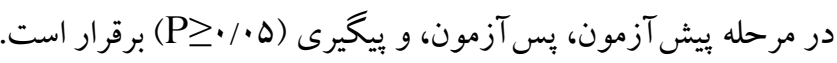
براى تجزيهو تحليل دادهها ابتدا آزمون تحليل واريانس با اندازه كيرى مكرر با عامل درون گروهى نمره ترس از ارزيابى منفى، نكرش به زندگى

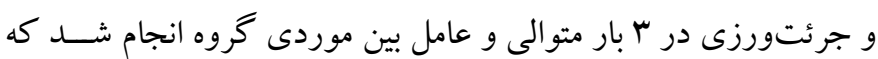
نتايج آن در جدول \& كزارش شده است.
بررسـى نتايج آزمون ام باكس متغيرهاى يزٔوهش نشـان مىدهد كه

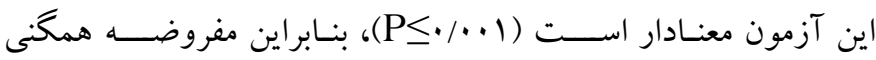
مـاتريس هـاى كوواريانس برقرار نيســت، اما با توجه به برابرى تعداد دو كروه مى توانيم از اين مفروضــه عبور كنيم. يُيشفرض آزمون كرويست

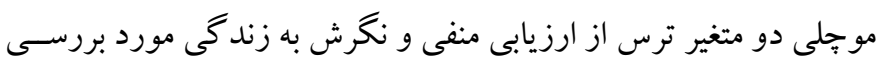

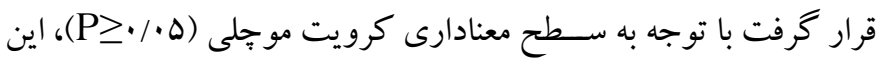
مفروضسه براى اين دو متغير برقرار اسـت، ولى در متغير جرئتورزى اين مفروضسه رعايت نشده است. با توجه به اينكه گمارش گروهها بهصورت 
جدول ع: آزمون تحليل واريانس جندمتغيره با اندازه كيرى مكرر براى اثرات درون كروهى و تعامل (لامبداى ويلكز)

\begin{tabular}{|c|c|c|c|c|c|}
\hline مجذور اتا & سطح معنادارى & $\mathbf{F}$ & مقدار & عامل & متغير \\
\hline$\cdot / A V Y$ & $\mathrm{P} \leq \cdot / \cdot \cdot 1$ & $1 Y / .90$ & . $/ \Delta Y A$ & زمان & ترس از ارزيابى منفى \\
\hline . & $\mathrm{P} \leq \cdot / \cdot \cdot 1$ & ID/DYY & $\cdot / 490$ & تعامل گروه و زمان & \\
\hline$\cdot / F M$ & $\mathrm{P} \leq \cdot / \cdot \cdot 1$ & IY/AGF &.$/ 014$ & زمان & نكرش به زندىى \\
\hline$\cdot / \Delta \Delta V$ & $\mathrm{P} \leq \cdot / \cdot \cdot 1$ & 19/914 & - par & تعامل گروه و زمان & \\
\hline . $/ 9 \Delta r$ & $\mathrm{P} \leq \cdot / \cdot \cdot 1$ & $r \Delta / r I l$ & $\cdot /$ THA & ز زمان & جرئتورزى \\
\hline$\cdot 19 \Delta \wedge$ & $\mathrm{P} \leq \cdot / \cdot \cdot 1$ & $r Q / . r \Lambda$ & . MFY & تعامل گروه و زمان & \\
\hline
\end{tabular}

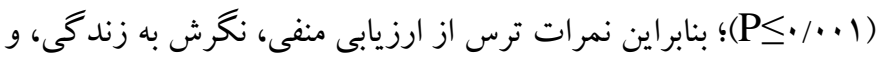

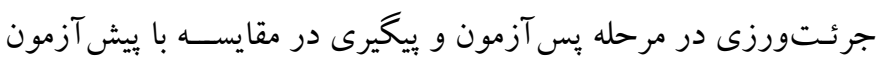

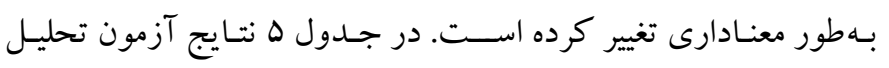

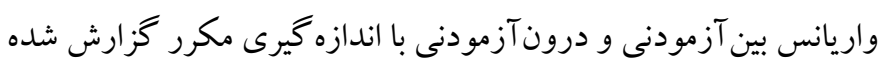

نتايج جدول \& نشــان مىدهد كه نمره ترس از ارزيابى منفى، نغرش

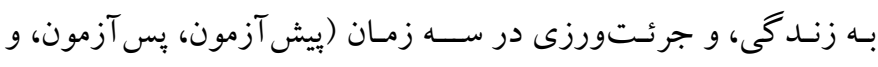

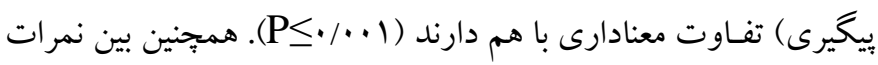

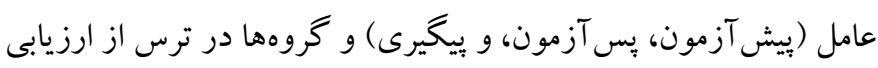

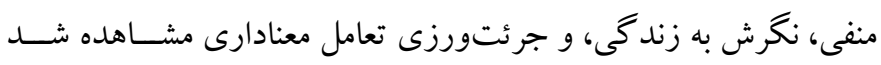

جدول ه: نتايج آزمون تحليل واريانس بين آزمودنى و درون آزمودنى با اندازهيرى مكرر

\begin{tabular}{|c|c|c|c|c|c|c|c|}
\hline مجذور اتا & سطح معنادارى & $\mathbf{F}$ & ميانكين مجذورات & درجه آزادى & مجموع مجذورات & عامل & متغير \\
\hline$\cdot / \pi M$ & $\mathrm{P} \leq \bullet / \cdot \cdot$ & $1 \cdot / \mathrm{Vrr}$ & $19.19 \mathrm{VA}$ & 1 & $19 \cdot 19 \mathrm{VA}$ & كروه & \\
\hline - /FAG & $\mathrm{P} \leq \cdot / \cdot \cdot 1$ & $r r / \Delta \cdot \Lambda$ & $\mid V r / 4 .$. & 1 & $\ln / 4 .$. & ز مان & ترس از ارزيابى منفى \\
\hline . / FrV & $\mathrm{P} \leq \cdot / \cdot \cdot 1$ & $11 / v \cdots$ & $r 9.1 .9 \mathrm{~V}$ & 1 & $r 9.1 .9 \mathrm{~V}$ & زمان * گروه & \\
\hline ( & $\mathrm{P} \leq \cdot / \cdot v$ & N/FVD & $r \Lambda \cdot / q .$. & 1 & $r \Lambda \cdot / 9 .$. & كروه & \\
\hline$\cdot / \pi / 9$ & $\mathrm{P} \leq \cdot / \cdots 1$ & $10 / 9 Q 4$ & $V r / 9 .$. & 1 & $V r / 9 \ldots$ & زمان & نخرش به زندگى \\
\hline . /Drq & $\mathrm{P} \leq \cdot / \cdot \cdot 1$ & $M I / r$. & $|F| / .9 \mathrm{~V}$ & 1 & $|F| / .9 \mathrm{~V}$ & زمان * گروه & \\
\hline
\end{tabular}

كروه آزمايش در مقـايســه بـا گروه گو اه، معنادار اســت. همجنين بين

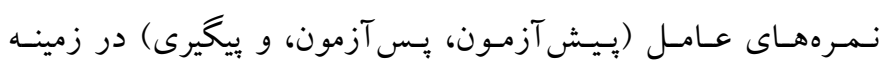

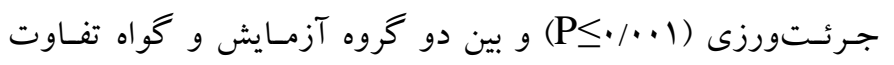

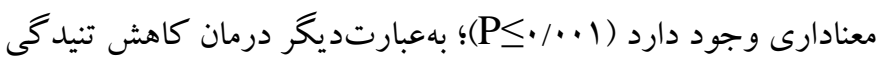

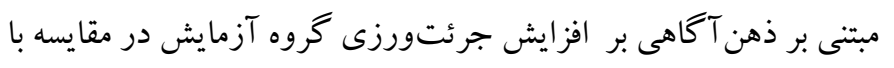

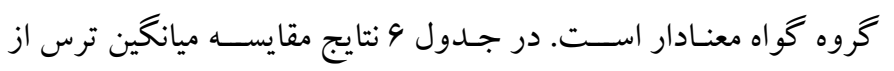

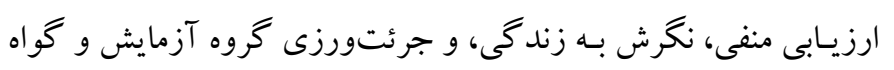

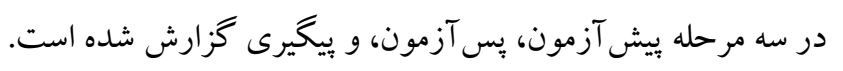

بـا توجه به جدول ها، بين نمرههاى عامل (بيش آزمون، بِ آزمون، و

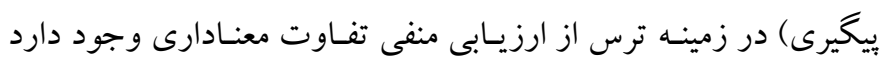

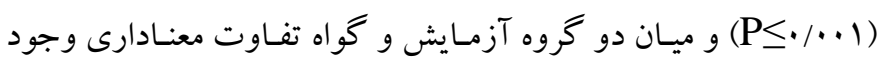

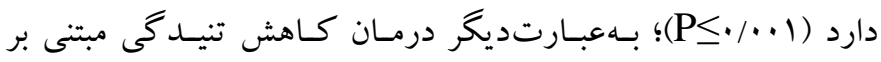

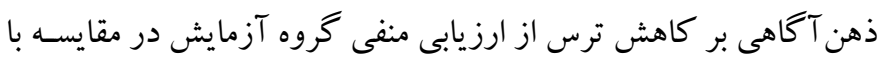

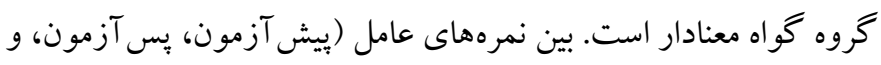

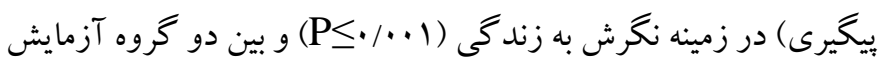

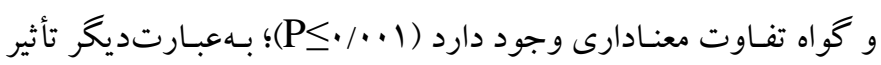

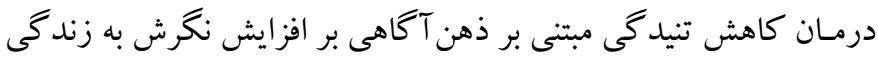




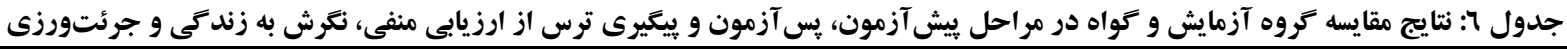

\begin{tabular}{|c|c|c|c|c|c|c|}
\hline سطح معنادارى & خطاى استاندارد & تفاوت ميانكينها & ميانكين كواه & ميانغين آزمايش & مرحله & متغير \\
\hline$\cdot|| F \mid$ & $1 / 4 \mid r$ & $1 / 9$ & $\mathrm{rV} / 99 \mathrm{~V}$ & $r q / Y q V$ & ييش آزمون & \\
\hline $\mathrm{P} \leq \cdot / \cdot \cdot 1$ & $1 / 499$ & $-\Delta / \kappa$ & rV/arr & rr/OMr & پֵ آزمون & ترس از ارزيابى منفى \\
\hline $\mathrm{P} \leq \bullet / \cdot \cdot$ & $1 / r v$. & $-F / 9 \pi r$ & rV/Drr & $r r / 9 .$. & ييخيرى & \\
\hline.$/ 91 Y$ & $\cdot / 110$ & $-\cdot 19$ & $Y F / \Lambda G V$ & YF/YGV & ييش آزمون & \\
\hline $\mathrm{P} \leq \cdot / \cdot \cdot 1$ & $1 / .49$ & $0 / 994$ & TF/KGV & $r \cdot / l \pi r$ & يس آزمون & نكرش به زندگى \\
\hline $\mathrm{P} \leq \cdot / \cdot \cdot 1$ &.$/ 909$ & D/DHT & rF & 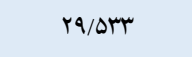 & يِيخيرى & \\
\hline.$/ 11 r$ & $1 / 491$ & $r / \cdot \Delta$ & $Q \Delta / \Delta \wedge F$ & $q \vee / 0 \wedge q$ & يِش آزمون & \\
\hline $\mathrm{P} \leq \bullet / \cdots 1$ & $1 / F \vee A$ & $r Y / 99 V$ & $q V / 4 q Q$ & $1 r \cdot / 949$ & يس آزمون & جرئتورزى \\
\hline $\mathrm{P} \leq \bullet / \cdot \cdot 1$ & $1 / 091$ & YF/AV & $Q \Delta / \Delta \wedge Q$ & $\mid r \cdot / 4 \Delta Q$ & ييخيرى & \\
\hline
\end{tabular}

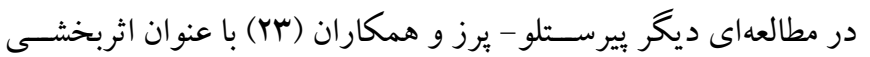

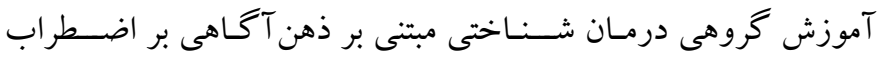

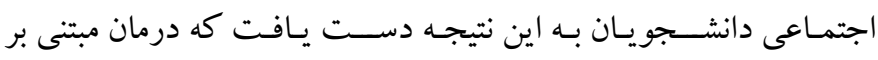
ذهن آكاهى بر كاهش اضـطر اب اجتماعى دانشـجويان تأثير مثبتى دارد.

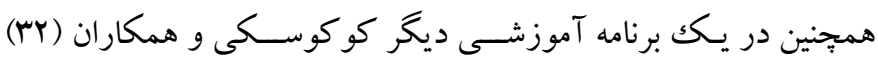

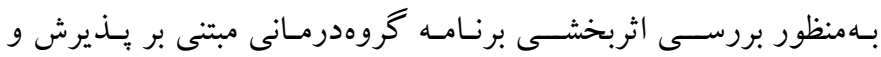

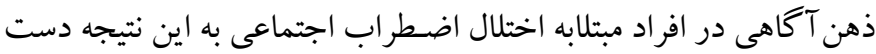

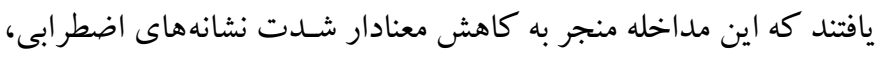

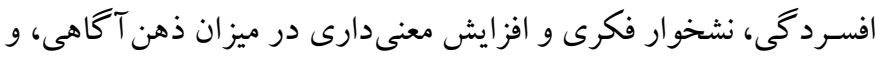
يذيرش مىشـود. بدين ترتيب نتايج اين مطالعات نيز در راستاى يافته هاى

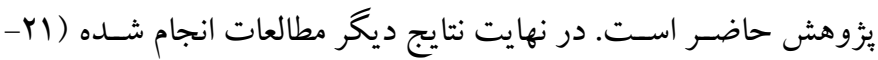

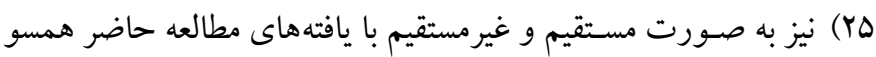

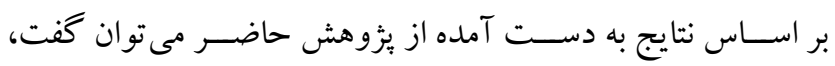

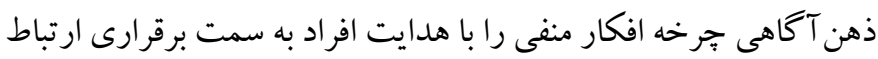

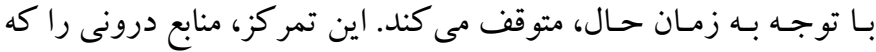

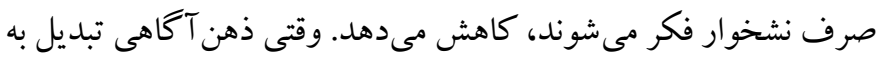

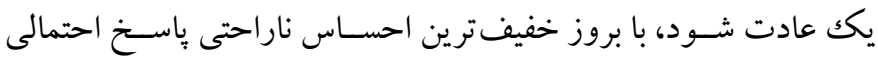

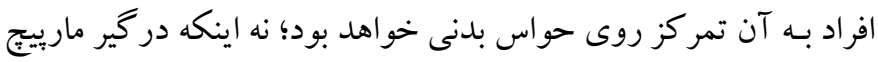

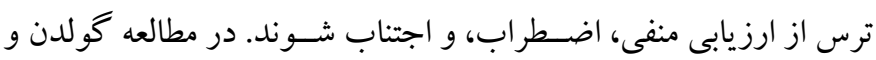

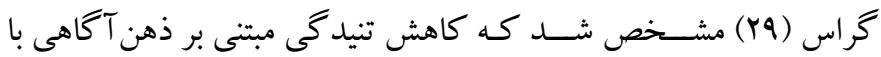

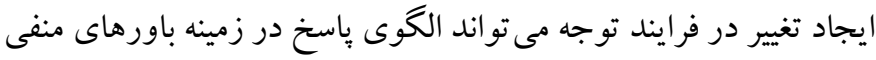

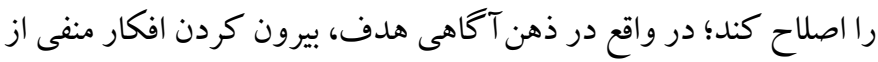

همان طور كه در جدول 9 ملاحظه مى شـود در متغير ترس از ارزيابى

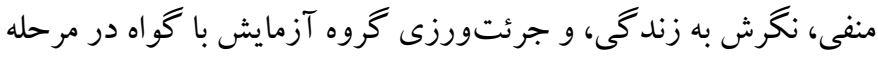

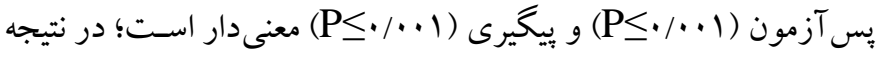

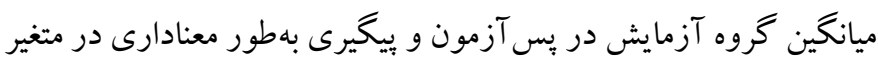

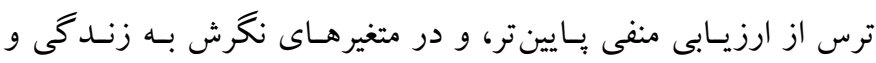

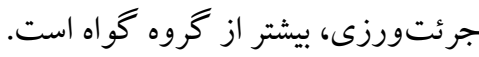

\section{بحث و نتيجه كيرى}

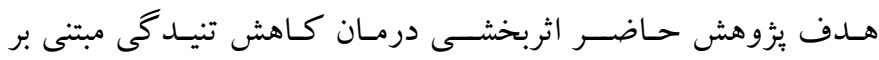

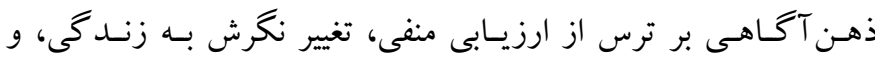

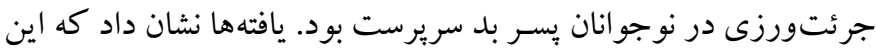

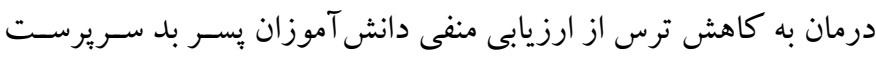
منجر شــده اسـت اين يافته يُوهش حاضــر با نتايج برخى يُزوهشهاى

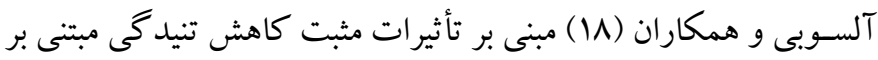

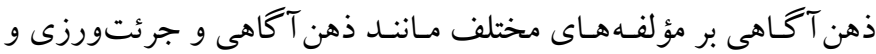

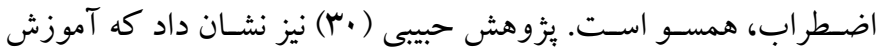

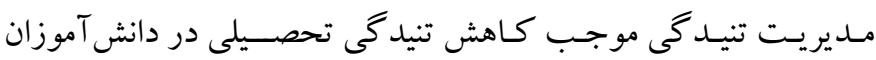
دبيرستانى مى شـود و يُزوهش محمد، بإييوس، و شرما (الr) نيز حاكى از

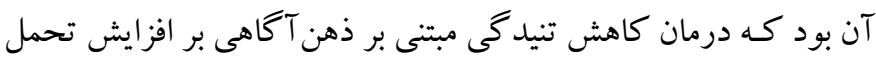

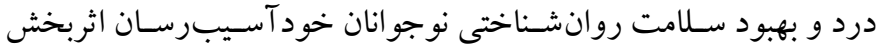

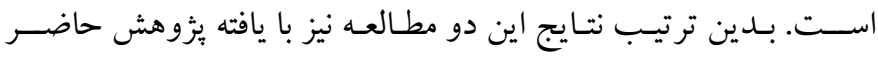

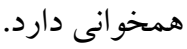


ذهن آكاهى با تشويق افراد به تمرين مكرر توجه روى محر كك هاى خنثى

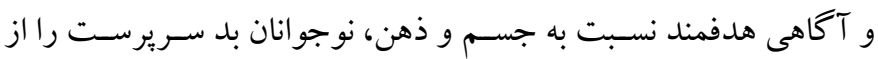

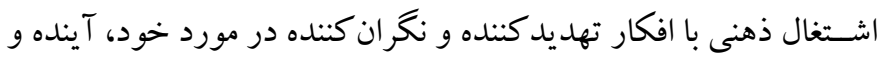

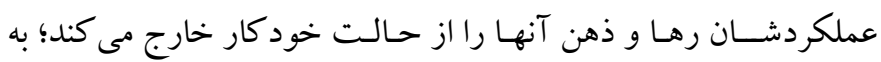

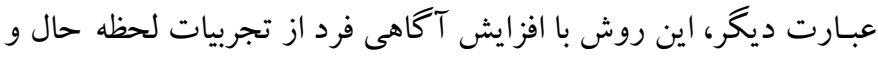

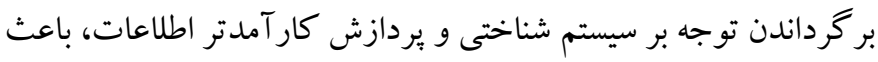

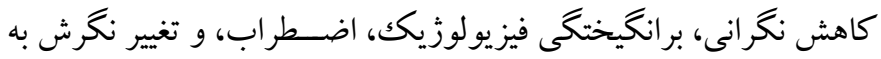

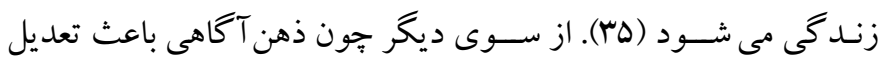

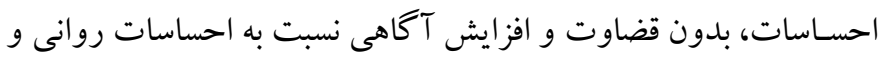
جسـمانى مى شــود و به واضسح ديدن و بذيرش هيجانات و بديدههاى

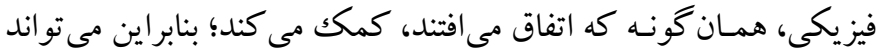

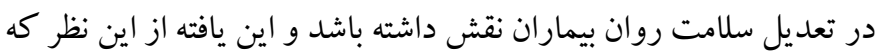

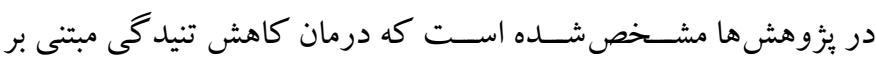
ذهن آكاهى در تعديل ترس از ارزيابى منفى و افكار منفى كمكك مى كند و موجب رفتارهاى مثبت مر تبط با سـلامتى مى شـود، قابل توجيه اسـت؛

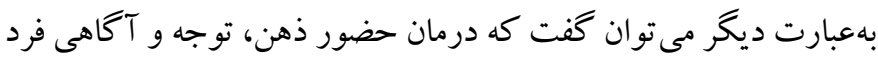
را نسـبت به احسـاسـات جسمانى و روانى بيشتر مى كند و احساس اعتماد

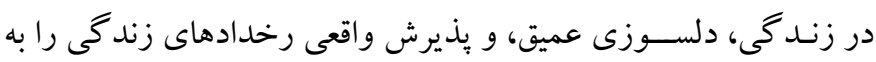

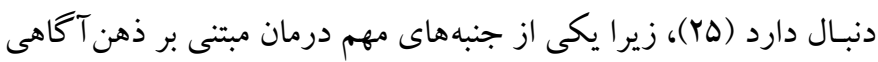

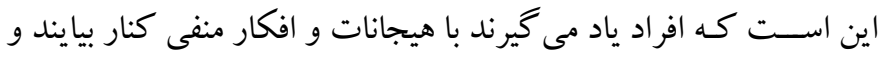

حوادث ذهنى را بهصورت مثبت تجربه كنند (צ)). همجينين نتايج نشـان داد درمان كاهش تنيدگى مبتنى بر ذهن آكاهى

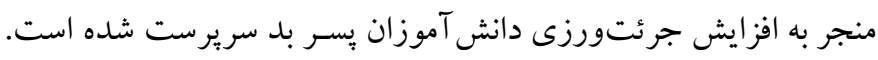

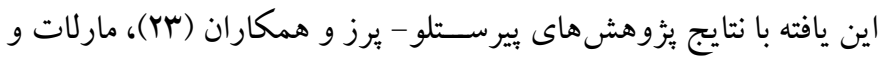

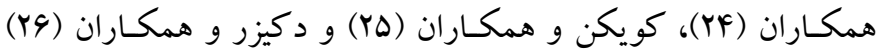

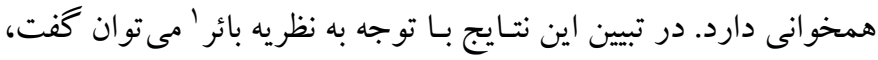

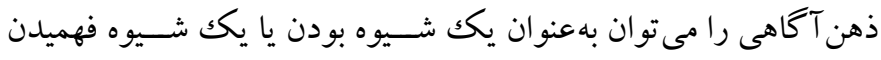

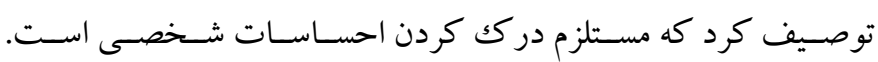
ذهن آكاهى روشى است براى ارتباط بهتر كه مى تواند دردهاى جسمانى

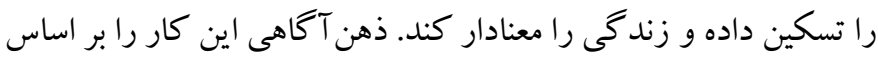

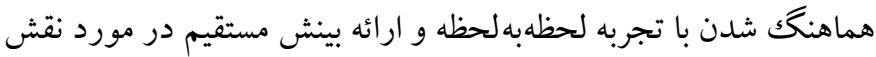

ذهن نيست، كه بيشخيرى از تحكيم اين افكار است. تبين ديخرى كه در مورد تأثير درمان كاهش تنيدگى مبتنى بر ذهن آكاهى بر كاهش ترس از

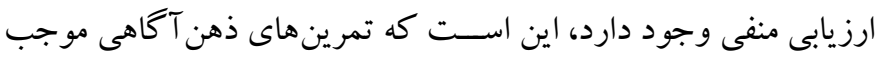
افزايـش توانـايى مراجعـان در تحمـل حـالـتهـاى هيجـانى منفى و احســاس هاى بلدنى ناراحت خواهد شـــــ و اين افراد را براى كنار آمدن

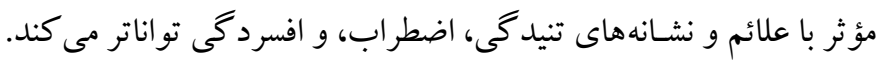

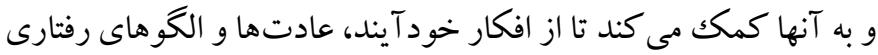
ناسـالم رها شـوند؛ بدين ترتيب اين مداخله نقش مهمى در تنظيم رفتارى

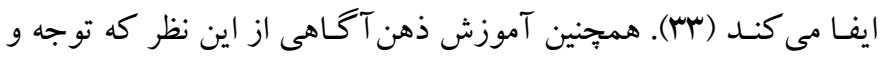
آكاهى فرد را نسـبت به احســاسـات فيزيكى و روانى بيشـتر مى كند و

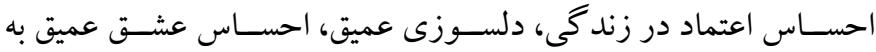

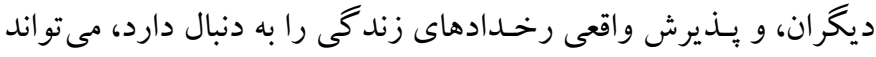

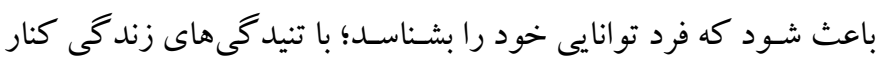

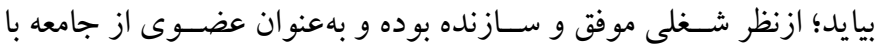

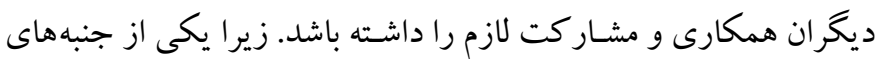

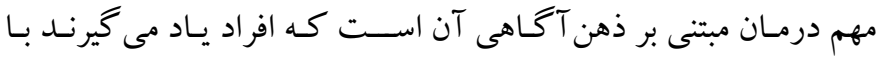

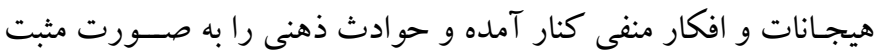

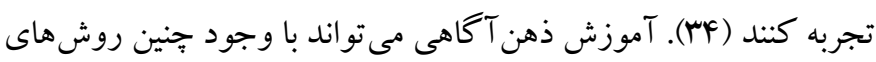

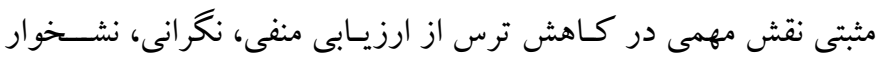
فكرى، اضطراب و علائم جسمانى داشته باشد.

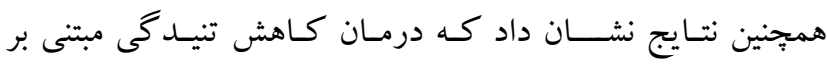

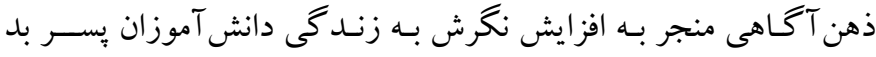

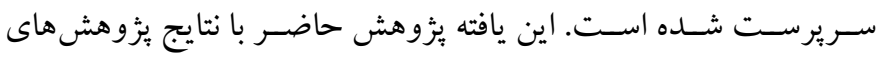

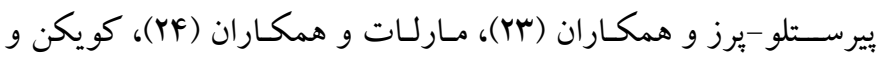

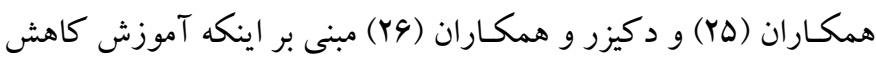

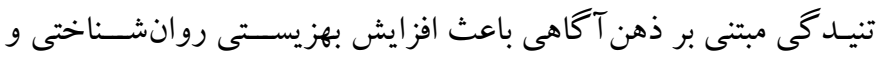

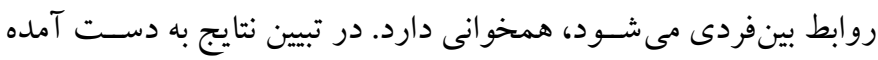

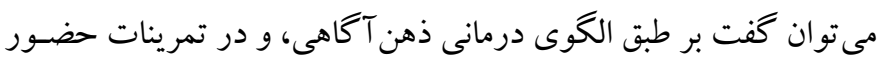

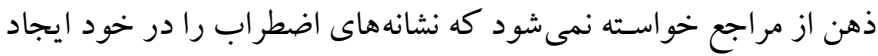

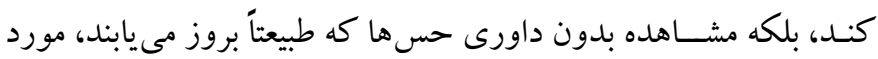

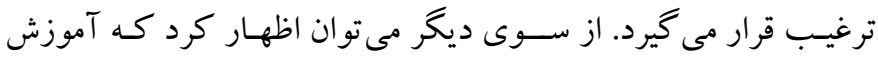




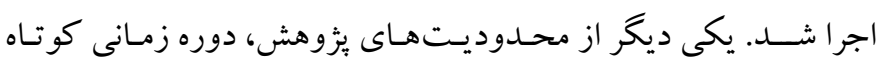

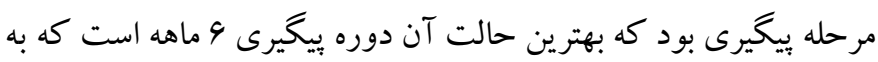

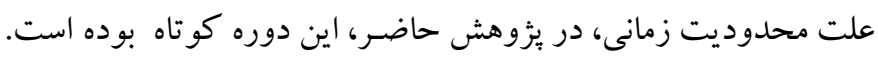

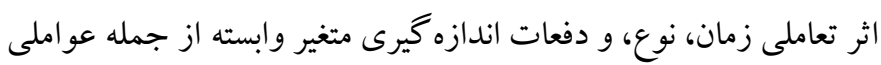

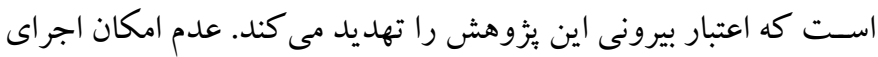

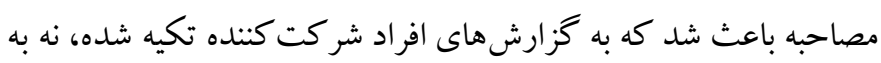

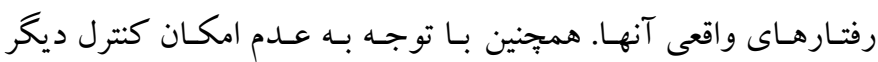

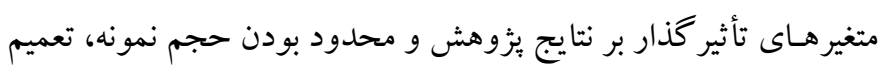

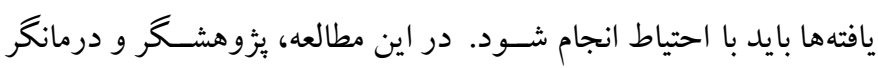

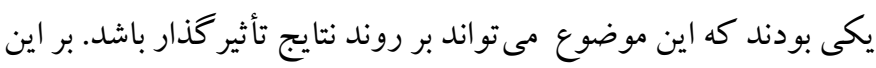

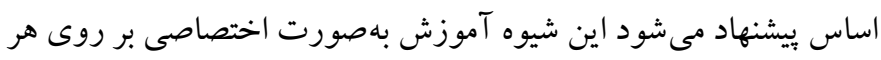

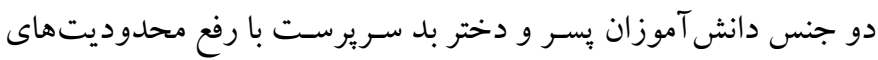

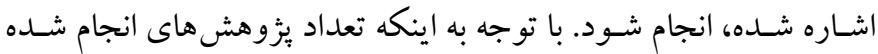

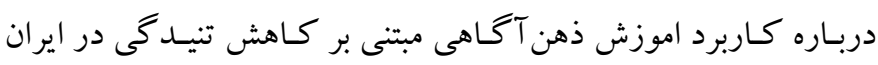

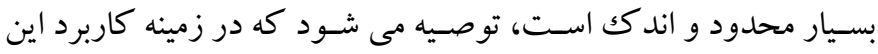

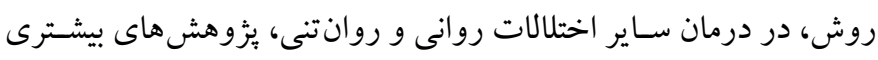

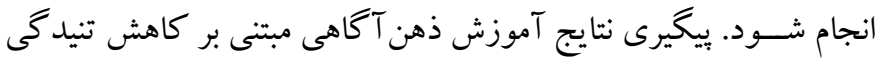

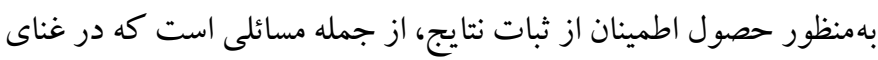
يافته هاى مطالعات مشابه، مؤثر خو اهد بو د.

تشـكر و قدردانى: اين مطالعه به صـورت مستقل اجرا شـده است و حاصل باياننامه يا طرح يزوهشـى مصسوب نيست. مجوز اجراى اين مطالعه نيز توسط

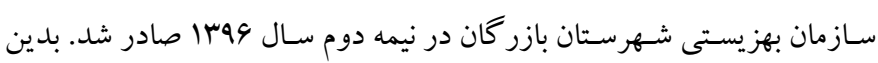

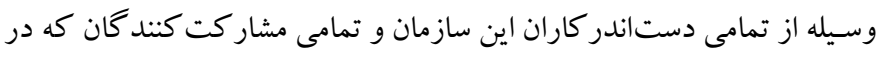
اجراى اين يزووهش مشار كت داشتند تشكر و قدردانى مى شود. تضــاد منافع: اين يُزوهش براى نويســند كان هيج كونه تضــاد منافع به دنبال

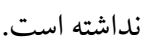

ذهـن در ايجـاد دلشــورههـاى بىمورد انجـام مىدهــ (سT). برخى

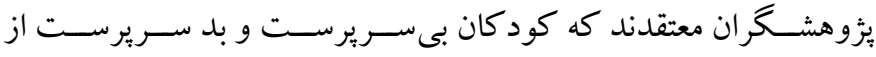
حرمتخود بايين، جرئتورزى همر اه با رفتارهاى برخاشخر انه، و كيفيت

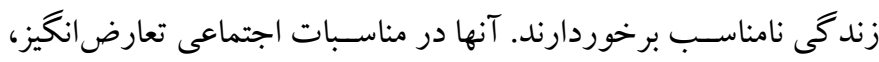

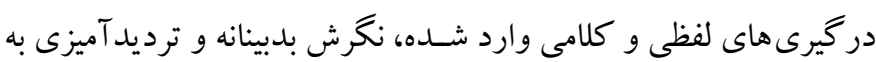

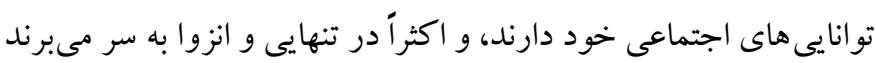

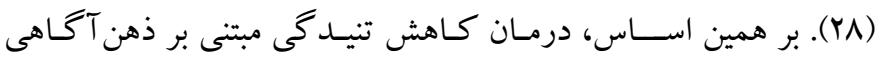

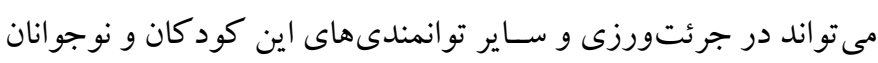

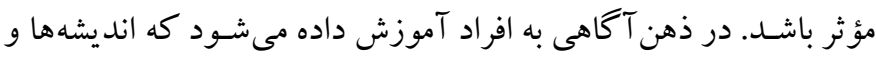

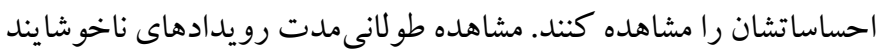
خصـوصى در طول زمان باعث كاهش اجتناب عاطفى از محر كك درونى

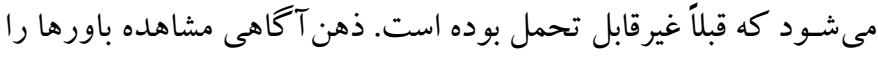

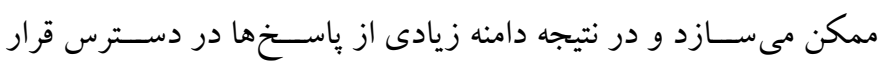

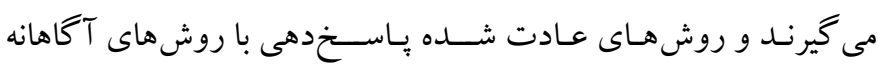

ياسخدهى كه غير خو كار انتخاب مى شوند جابه جا مى شوند (TV). يزٔوهش حاضـر با محدوديتهايى روبرو بوده اسـت كه بيان آنها در

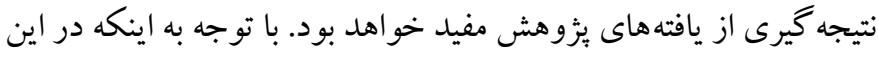

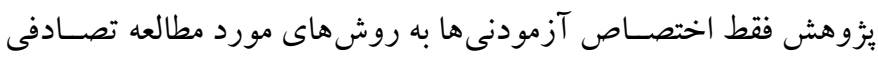

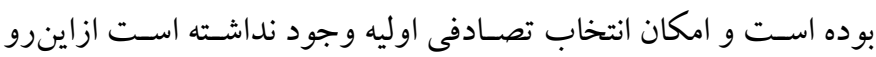

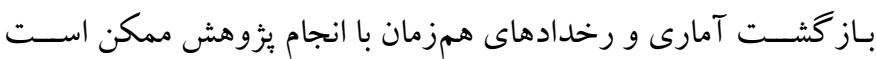

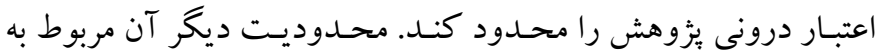

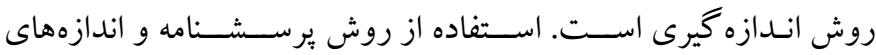

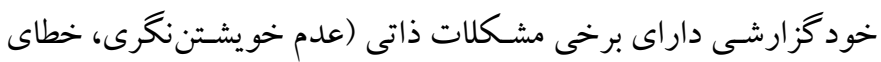

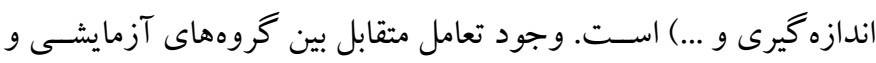

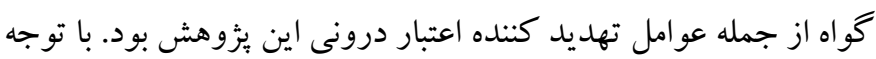

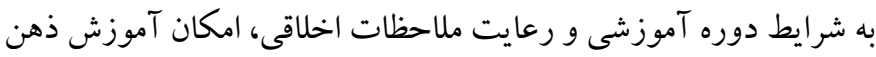
آكاهى به دختران بد سريرست امكانيذير نبود، به همين دليل تنها از ميان

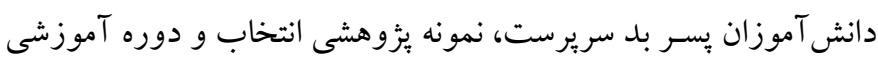




\section{References}

1. Giagazoglou P, Kouliousi C, Sidiropoulou M, Fahantidou A. The effect of institutionalization on psychomotor development of preschool aged children. Res Dev Disabil. 2012; 33(3): 964-970. [Link]

2. War FA, Ved RS, Paul MA. Mental health and selfesteem of institutionalized adolescents affected by armed conflict. J Relig Health. 2016; 55(2): 593-601. [Link]

3. Rajabi M, Bagiyan MJ, Bakhti M, Kariminejad K. Comparison of mental health indicators in orphaned children held centers with children deposited to relatives in Lorestan province. Journal of Pediatric Nursing. 2017; 4(1): 36-42. [Persian]. [Link]

4. Hesarsorkhi R, Asghari Nekah SM, Lalzdeh Kandekali E, Parvaneh E. Comparison of aggression and emotional knowledge in orphans and abandoned male children with non- orphans male children. Quarterly Journal of Child Mental Health. 2016; 3(2): 77-85. [Persian]. [Link]

5. Saffarhamidi E, Hosseininan S, Zandipour T. The effect of positive thinking education on the perceived competency and social skills of the orphan and mistreated children. Quarterly Journal of Child Mental Health. 2017; 4(1): 13-23. [Persian]. [Link]

6. Keil M. A prospective study of growth and development of children recently adopted from orphanage care. J Pediatr Nurs. 2012; 27(3): e3. [Link]

7. Craven M. Effects of self-focused attention and fear of evaluation on anxiety and perception of speech performance [Electronic Thesis]. [Ohio, United States]: The College of Arts and Sciences, Ohio University; 2015, pp: 1-59. [Link]

8. Ganesh Kumar J, Athilakshmi R, Maharishi R, Maya R. Relationship between fear of negative evaluation and anxiety. The International Journal of Indian Psychology. 2015; 3(1): 47-80. [Link]

9. Weeks JW, Howell AN. The bivalent fear of evaluation model of social anxiety: Further integrating findings on fears of positive and negative evaluation. Cogn Behav Ther. 2012; 41(2): 83-95. [Link]

10. Sultan S, Kanwal F. Gender differences in selfhandicapping: the role of self-esteem and fear of negative evaluation. Journal of Gender \& Social Issues. 2014; 13(1): 45-56. [Link]

11.Bekker MH, Croon MA, van Balkom EG, Vermee JB. Predicting individual differences in autonomyconnectedness: the role of body awareness, alexithymia, and assertiveness. J Clin Psychol. 2008; 64(6): 747-765. [Link]
12. Shalchi B, Vahidnia B, Dadkhah M, Alipouri Niaz M, Moghimifam P. Comparation of affective -behavioral disorders and social skills among normal adolescents and institutional children of social welfare bureau. Social Welfare Quarterly. 2018; 17(67): 173-201. [Persian]. [Link]

13.Sevillano-Jiménez A, Ruano-García C. Assertive community treatment as a method of care in mental health. Role of the specialist nurse. Enferm Clin. 2019; 29(6): 387-389. [Link]

14. Masters JC, Burish TG, Hollon SD, Rimm DC. Behavior therapy: techniques and empirical findings. Subsequent edition. San Diego: Harcourt College Pub; 1987. [Link]

15.James K, Rimes KA. Mindfulness-based cognitive therapy versus pure cognitive behavioural self-help for perfectionism: a pilot randomised study. Mindfulness (N Y). 2018; 9(3): 801-814. [Link]

16.van der Velden AM, Roepstorff A. Neural mechanisms of mindfulness meditation: bridging clinical and neuroscience investigations. Nat Rev Neurosci. 2015; 16(7): 439-439. [Link]

17.Segal ZV, Teasdale JD, Williams JM, Gemar MC. The mindfulness-based cognitive therapy adherence scale: inter-rater reliability, adherence to protocol and treatment distinctiveness. Clin Psychol Psychother. 2002; 9(2): 131-138. [Link]

18. Alsubaie M, Abbott R, Dunn B, Dickens C, Keil TF, Henley $\mathrm{W}$, et al. Mechanisms of action in mindfulness-based cognitive therapy (MBCT) and mindfulness-based stress reduction (MBSR) in people with physical and/or psychological conditions: a systematic review. Clin Psychol Rev. 2017; 55: 74 91. [Link]

19.Eisendrath SJ, Gillung E, Delucchi KL, Segal ZV, Nelson JC, McInnes LA, et al. A Randomized controlled trial of mindfulness-based cognitive therapy for treatment-resistant depression. Psychother Psychosom. 2016; 85(2): 99-110. [Link]

20.Malinowski P. Neural mechanisms of attentional control in mindfulness meditation. Front Neurosci. 2013; 7: 8. [Link]

21.Horton-Deutsch SL, Horton JM. Mindfulness: overcoming intractable conflict. Arch Psychiatr Nurs. 2003; 17(4): 186-193. [Link]

22.Davis DM, Hayes JA. What are the benefits of mindfulness? A practice review of psychotherapy related research. American Psychological Association. 2011; 48(2): 198-208. [Link]

23.Perestelo-Perez L, Barraca J, Peñate W, RiveroSantana A, Alvarez-Perez Y. Mindfulness-based 
interventions for the treatment of depressive rumination: Systematic review and meta-analysis. Int J Clin Health Psychol. 2017; 17(3): 282-295. [Link]

24. Marlatt GA, Bowen S, Chawla N, Witkiewitz K. Mindfulness-Based relapse prevention for substance abusers: therapist training and therapeutic relationships. In: Hick S, Bien T, editor. Mindfulness and the therapeutic relationship. New York: Guilford Press; 2008. pp: 1-21. [Link]

25.Kuyken W, Warren FC, Taylor RS, Whalley B, Crane C, Bondolfi G, et al. Efficacy of mindfulness-based cognitive therapy in prevention of depressive relapse. JAMA Psychiatry. 2019; 73(6): 565-574. [Link]

26.Dekeyser M, Raes F, Leijssen M, Leysen S, Dewulf D. Mindfulness skills and interpersonal behaviour. Pers Individ Dif. 2008; 44(5): 1235-1245. [Link]

27.Rahman W, Mullick MS, Pathan MA, Chowdhury NF, Shahidullah $\mathrm{M}$, Ahmed $\mathrm{H}$, et all. Prevalence of behavioral and emotional disorders among the orphans and factors associated with these disorders. Bangabandhu Sheikh Mujib Medical University Journal. 2012; 5(1): 29-34. [Link]

28. Yendork JS, Somhlaba NZ. Stress, coping and quality of life: An exploratory study of the psychological well-being of Ghanaian orphans placed in orphanages. Child Youth Serv Rev. 2014; 46: 28-37. [Link]

29. Goldin PR, Gross JJ. Effects of mindfulness based stress reduction (MBSR) on emotion regulation in social anxiety disorder. Emotion. 2010; 10(1): 83-91. [Link]

30.Habibi M. The effect of cognitive-behavioral stress management on decreasing academic expectation stress of parents: A case of first grade high school students. Journal of School Psychology. 2015; 4(2): 22-38. [Persian]. [Link]

31. Mohammed WA, Pappous A, Sharma D. Effect of mindfulness based stress reduction (MBSR) in increasing pain tolerance and improving the mental health of injured athletes. Front Psychol. 2018; 9: 722. [Link]

32.Kocovski NL, Fleming JE, Hawley LL, Huta V, Antony MM. Mindfulness and acceptance-based group therapy versus traditional cognitive behavioral group therapy for social anxiety disorder: A randomized controlled trial. Behav Res Ther. 2013; 51(12): 889-898. [Link]

33.Hazlett-Stevens H. Mindfulness-based stress reduction in a mental health outpatient setting: Benefits beyond symptom reduction. J Spiritual Ment Health. 2018; 20(3): 275-292. [Link]
34. O’Driscoll M, Sahm LJ, Byrne H, Lambert S, Byrne S. Impact of a mindfulness-based intervention on undergraduate pharmacy students' stress and distress: quantitative results of a mixed-methods study. Curr Pharm Teach Learn. 2019; 11(9): 876-887. [Link]

35.Björkstrand J, Schiller D, Li J, Davidson P, Rosén J, Mårtensson J, et al. The effect of mindfulness training on extinction retention. Sci Rep. 2019; 9: 19896. [Link]

36. Boyd JE, Lanius RA, McKinnon MC. Mindfulnessbased treatments for posttraumatic stress disorder: a review of the treatment literature and neurobiological evidence. J Psychiatry Neurosci. 2018; 43(1): 7-25. [Link]

37.Parsons CE, Crane C, Parsons LJ, Fjorback LO, Kuyken W. Home practice in mindfulness-based cognitive therapy and mindfulness-based stress reduction: a systematic review and meta-analysis of participants' mindfulness practice and its association with outcomes. Behav Res Ther. 2017; 95: 29-41. [Link]

38.Leary MR. A brief version of the Fear of Negative Evaluation Scale. Pers Soc Psychol Bull. 1983; 9(3): 371-375. [Link]

39. Collins KA, Westra HA, Dozois DJ, Stewart SH. The validity of the brief version of the fear of negative evaluation scale. J Anxiety Disord. 2005; 19(3): 345359. [Link]

40.Shokri O, Geravand F, Naghsh Z, Ali Tarkhan R, Paeezi M. the psychometric properties of the brief fear of negative evaluation scale. Iranian Journal of Psychiatry and Clinical Psychology. 2008; 14(3): 316-325. [Persian]. [Link]

41. Battista J, Almond R. The development of meaningful life. Psychiatry. 1973; 36(4): 409-427. [Link]

42.Haji Abed MR, Bagheri F, Asghar Nejad Farid AA. Comparison of life regard index between veterans suffering from post traumatic stress disorder with and without history of substance abuse in Shahid Rajaee Hospital in Isfahan. Iranian Journal of War and Public Health. 2013; 5(2): 10-17. [Persian]. [Link]

43. Gambrill ED, Richey CA. An assertion inventory for use in assessment and research. Behav Ther. 1975; 6(4): 550-561. [Link]

44.Rezapour Mirsaleh Y, Aboutorabi Kashani P, Ebrahimi Ghavam S. Effectiveness of assertive skills training on improvement of assertion and self-esteem of third to fifth grade low-assertive girl students in Tehran. Scientific Journal of Clinical Psychology \& Personality. 2013; 2(7): 77-90. [Persian]. [Link] 
45.Segal Z, Williams M, Teasdale J, Crane R, Dimidjian $\mathrm{S}$, Ma $\mathrm{H}$, et al. Mindfulness-based cognitive therapy training pathway. Version 1.0. Oxford Mindfulness Centre; 2016, pp: 1-13. [Link] 